\title{
Altered Fatty Acid Profile in the Liver and Serum of Stroke-Prone Spontaneously Hypertensive Rats: Reduced Proportion of cis-Vaccenic Acid
}

\author{
Shizuyo Tanaka ${ }^{1}$, Chiho Kojiguchi ${ }^{1}$, Tohru Yamazaki ${ }^{1}$, Atsushi Mitsumoto ${ }^{2}$, \\ Daisuke Kobayashi ${ }^{1}$, Naomi Kudo ${ }^{1}$ and Yoichi Kawashima ${ }^{1 *}$ \\ ${ }_{1}^{1}$ Faculty of Pharmaceutical Sciences, Josai University (1-1 Keyakidai, Sakado, Saitama 350-0295, Japan) \\ ${ }^{2}$ Faculty of Pharmaceutical Sciences, Josai International University (1 Gumyo, Togane, Chiba 283-8555, Japan)
}

\begin{abstract}
Stroke-prone spontaneously hypertensive rats (SHRSP) are utilized as models for study of the pathogenesis of not only stroke and cardiovascular disorders but also atherosclerosis and metabolic syndrome. Basic information on the profiles of fatty acids and lipid classes in the liver is indispensable to use SHRSP as a model of disorder of lipid metabolism; nevertheless, detailed information on the metabolism of triacylglycerols (TAGs) and fatty acids in the liver of SHRSP is lacking. This study aimed to characterize profiles of lipid classes and fatty acids and to explore the mechanism underlying the characteristic alterations in metabolism of TAGs and fatty acids in the liver of SHRSP, in comparison with spontaneously hypertensive rats (SHR). The characteristic changes observed in SHRSP were (1) markedly lower hepatic TAG contents; (2) altered expressions of genes encoding three enzymes responsible for the control of TAG level, namely, adipose triglyceride lipase (for TAG degradation; up-regulated), carnitine palmitoyltransferase 1a (for fatty acid $\beta$-oxidation; up-regulated) and long-chain acyl-CoA synthetase 3 (for glycerolipid synthesis; down-regulated); (3) evidently lower contents and proportions of monounsaturated fatty acids, in particular cis-vaccenic acid (18:1n-7), in the liver and serum; and (4) down-regulation of palmitoleoyl-CoA chain elongase, which is necessary for the biosynthesis of 18:1n-7, in the liver. From the above observations, we concluded that there are significant differences in profiles of lipid classes and fatty acids between SHRSP and SHR, and that altered characteristics in SHRSP are likely responsible for increases in TAG hydrolysis and $\beta$-oxidation, and decreases in TAG synthesis and 18:1n-7 synthesis.
\end{abstract}

Key words: stroke-prone spontaneously hypertensive rat, fatty acid profile, cis-vaccenic acid, triacylglycerol, liver

Abbreviations: ACC1, Acetyl-CoA carboxylase 1; ACLY, ATPcitrate lyase; ACSL, Long-chain acyl-CoA synthetase; ATGL, Adipose triglyceride lipase; CE, Cholesteryl ester; ChREBP, Carbohydrate responsive element-binding protein; CPT1a, Carnitine palmitoyltransferase 1a; DAG, Diacylglycerol; DGAT, Acyl-CoA:diacylglycerol acyltransferase; Elovl, Fatty acid elongase; FABP, Fatty acid binding protein; FABPpm, Plasma membrane-associated fatty acid binding protein; Fads, Fatty acid desaturase; FAS, Fatty acid synthase; FAT/CD36, Fatty acid translocase; FATP, Fatty acid transport protein; FFA, Unesterified fatty acid; GK, Glucokinase; GLUT2, Glucose transporter 2; GPAT, Glycerol-3-phosphate acyltransferase; G6Pc, Glucose-6-phosphatase; LCAD, Long-chain acyl-CoA dehydrogenase; LPK, L-type pyruvate kinase; LXR $\alpha$, Liver X receptor $\alpha$; MCAD, Medium-chain acyl-CoA dehydrogenase; ME1, Malic enzyme 1; PCE, Palmitoyl-CoA chain elongase; POCE, Palmitoleoyl-CoA chain elongase; PCR, Polymerase chain reaction; PEPCK, Phosphoenolpyruvate carboxykinase; PPAR $\alpha$, Peroxisome proliferator-activated receptor $\alpha$; PL, Phospholipid; SCD, Stearoyl-CoA desaturase; SHR, Spontaneously hypertensive rats; SHRSP, Stroke-prone spontaneously hypertensive rats; SREBP-1c, Sterol regulatory element binding protein-1c; TAG, Triacylglycerol; WKY, Wistar Kyoto rats;

\section{INTRODUCTION}

The stroke-prone spontaneously hypertensive strain of rats is a substrain of spontaneously hypertensive rats (SHR), which were spontaneously developed as a colony from normotensive Wistar Kyoto rats (WKY ${ }^{1-3)}$. The stroke-prone spontaneously hypertensive rats (SHRSP) develop severe hypertension with age and die from stroke due to infarction and hemorrhage; moreover, a reduction of

\footnotetext{
*Correspondence to: Yoichi Kawashima, Faculty of Pharmaceutical Sciences, Josai University, 1-1 Keyakidai, Saitama 350-0295, Japan

E-mail: ykawash@josai.ac.jp

Accepted June 11, 2013 (received for review May 3, 2013)

Journal of Oleo Science ISSN 1345-8957 print / ISSN 1347-3352 online

http://www.jstage.jst.go.jp/browse/jos/ http://mc.manusriptcentral.com/jjocs
} 
cerebral blood flow has been confirmed during the development of hypertension in SHRSP. Thus, the etiology of stroke in these rats is essentially similar to that in humans ${ }^{2-4)}$. In addition to severe hypertension, SHRSP exhibit a series of cardiovascular disorders such as salt sensitivity, stress sensitivity and the propensity for end-organ damage ${ }^{5,6)}$. SHRSP develop severe nephrosclerosis and hypertensioninduced renal injury as well ${ }^{2,7)}$. SHRSP also exhibit behavioral abnormalities including increased ambulatory activity and disrupted circadian rhythms; these behavioral abnormalities are considered to correspond to the delirium state observed in patients with dementia after cerebrovascular accidents ${ }^{8)}$. On the one hand, SHRSP are hyper-responders to cholesterol feeding and easily develop hyperlipidemia and arterial fat deposition ${ }^{9)}$. SHR, which present with a predisposition to insulin resistance, have been used to identify genes contributing to metabolic syndrome ${ }^{10)}$. In this context, not a small number of studies have utilized SHRSP as a model of not only stroke but also disorders of lipid metabolism, in particular the early changes underlying the development of metabolic syndrome ${ }^{11}$. Thus, SHRSP are considered to be useful for study of the pathogenesis of the above-mentioned disorders and for testing of likely prophylactic compounds against them. Many types of compound, including drugs, dietary oils, fatty acids and other nutrients, have been tested so far. From these studies, several types of fatty acid and dietary oil have been demonstrated to affect(prevent, ameliorate or exacerbate) the above-mentioned disorders ${ }^{12-18)}$.

Attention has been increasingly focused on the quality rather than the quantity of fatty acids since fatty acid species are of crucial importance for many physiological processes, such as de novo lipogenesis ${ }^{19)}$, gluconeogene$\mathrm{sis}^{20)}$, triacylglycerol (TAG) synthesis ${ }^{21)}$, secretion of verylow density lipoprotei ${ }^{22)}$, endoplasmic reticulum stress ${ }^{23)}$, insulin sensitivity ${ }^{24)}$ and obesity ${ }^{25)}$. These findings emphasize the importance of understanding the mechanism regulating the production of fatty acid species. Moreover, the liver plays a key role in whole-body fatty acid metabolism, and fatty acid species that exist in the liver are considered to be pathophysiologically critical ${ }^{23,26,27)}$. With regard to SHRSP, the lipid profile and fatty acid profile in renal membrane have been studied in relation to hypertension ${ }^{28)}$. To the best of our knowledge, however, information on the profile of fatty acids and lipids in the liver and serum of SHRSP is lacking; moreover, the mechanism underlying the changes in fatty acid metabolism in the liver of SHRSP is unclear. This information is indispensable to establish SHRSP as a useful model for pathophysiological study of lipid metabolism. In this context, the aims of this study are (1) to explore profiles of fatty acids and lipids in the liver and serum of SHRSP and (2) to investigate the mechanism underlying characteristic alterations in the metabolism of TAGs and fatty acids in the liver of SHRSP in comparison with SHR.

\section{EXPERIMENTAL PROCEDURES}

\subsection{Materials}

The following materials were obtained from the indicated commercial sources: L- $\left[\mathrm{U}-{ }_{-}^{14} \mathrm{C}\right]$ glycerol-3-phosphate (159 $\mathrm{Ci} / \mathrm{mol})$ and $\left[2{ }^{14} \mathrm{C}\right]$ malonyl-CoA $(56.0 \mathrm{Ci} / \mathrm{mol})$ (GE Healthcare, Little Chalfont, Buckinghamshire, UK); $\left[1-{ }^{14} \mathrm{C}\right]$ palmitoyl-CoA $(60.0 \mathrm{Ci} / \mathrm{mol})$ (Moravek Biochemicals, Inc., Brea, CA, U.S.A.); acetyl-CoA, malonyl-CoA, palmitoyl-CoA, stearoyl-CoA, L-glycerol-3-phosphate and bovine serum albumin (essentially fatty acid free for enzyme assays and fraction V for protein assay) (Sigma Aldrich Japan, Tokyo, Japan); 1,2-dioleoyl-sn-glycerol(Doosan Serdary Research Laboratories, Etobicoke, Ontario, Canada); nonadecanoic acid, methyl heptadecanoate, cholesteryl heptadecanoate and triheptadecanoin (Nu-Chek-Prep Inc., Elysian, MN, U.S.A.); L-phosphatidylcholine and L-phosphatidyl- L-serine (Avanti Polar Lipids Inc., Alabaster, AL, U.S.A.); nicotinamide adenine dinucleotide reduced (NADH) and nicotinamide adenine dinucleotide phosphate reduced (NADPH) (Oriental Yeast Co., Tokyo, Japan).

\subsection{Animals}

All animal procedures were approved by Josai University's Institutional Animal Care Committee in accordance with the Guidelines for Proper Conduct of Animal Experiments (Science Council of Japan). Fifteen-week-old male WKY, SHR and SHRSP were obtained from SLC (Hamamat$\mathrm{su}$, Japan). The animals were fed on a standard diet (CE-2; Clea Japan, Tokyo, Japan) ad libitum and allowed free access to water. After acclimatization, at the age of 22 weeks, the rats were anesthetized with diethyl ether. Blood was collected from the inferior vena cava and the liver was rapidly removed. Serum was obtained from the blood by centrifugation. The livers were washed with saline and weighed. For analyses of lipids and determination of mRNA, small portions of the liver were frozen in liquid nitrogen and stored at $-80^{\circ} \mathrm{C}$. The residual portion of the liver was perfused with ice-cold saline and used for the preparation of cytosol and microsomes.

\subsection{Preparation of cytosol and microsomes}

One portion of the liver was homogenized with 1.5 volumes of a phosphate-bicarbonate buffer $(70 \mathrm{mM}$ $\mathrm{KHCO}_{3} / 85 \mathrm{mM} \mathrm{K}_{2} \mathrm{HPO}_{4} / 9 \mathrm{mM} \mathrm{KH} \mathrm{PO}_{4} / 1 \mathrm{mM}$ dithiothreitol) ( $\mathrm{pH}$ 8.0) in a Potter glass-Teflon homogenizer. The homogenates were centrifuged at $20,000 \times \mathrm{g}$ for $10 \mathrm{~min}$, and the supernatant was centrifuged at $105,000 \times \mathrm{g}$ for $60 \mathrm{~min}$. The resulting supernatant was used as cytosol. The other portion of the perfused livers was used for the preparation of microsomes as described previously ${ }^{29)}$. All operations 
were carried out at $0-4^{\circ} \mathrm{C}$. Protein concentrations in the preparations were determined by the method of Lowry et $a l .^{30)}$ using bovine serum albumin as a standard.

\subsection{Analytical procedures}

Total lipid was extracted from portions of livers and serum by the method of Bligh and Dyer ${ }^{31)}$. Cholesterol in the liver and serum was measured by the method of Zurkowski $^{32)}$; lipid phosphorus was measured according to Rouser et $a l^{33)}$. TAG was separated by thin-layer chromatography on silica gel G plates, which were developed with n-hexane/diethyl ether/acetic acid (80:30:1, by vol.). After visualization by spraying $0.001 \%(\mathrm{w} / \mathrm{v})$ primuline in $80 \%$ acetone, the regions that corresponded to TAG were scraped off and transferred to tubes. TAG was extracted from silica gel as described previously ${ }^{29)}$, and determined by an enzymatic method using a commercially available kit (Triglyceride E-Test Wako; Wako Pure Chemical Industries, Ltd., Osaka, Japan) essentially according to Flowers et $a l .{ }^{34}$. TAG in serum was directly determined by the enzymatic method mentioned above. Glycogen contents in the livers were measured by the enzymatic method as described previously ${ }^{35)}$.

To determine the acyl composition of lipid classes, total lipids were extracted from portions of livers by the method of Bligh and Dyer ${ }^{31)}$, after the additions of known amounts of nonadecanoic acid, cholesteryl heptadecanoate and triheptadecanoin as internal standards. The acyl composition of hepatic total lipids was determined as methyl esters of fatty acids by gas chromatography (Shimadzu GC-2014; Shimadzu, Kyoto, Japan) as described previously ${ }^{36)}$. For cholesteryl ester(CE), TAG, unesterified fatty acid (FFA), diacylglycerol (DAG) and phospholipid (PL), these lipids were separated by thin-layer chromatography on silica gel G plates, which were developed with $n$-hexane/diethyl ether/acetic acid (80:30:1, by vol.). After visualization by spraying $0.001 \%(\mathrm{w} / \mathrm{v})$ primuline in $80 \%$ acetone, the regions on each plate that corresponded to specific lipids were scraped off and transferred to tubes. To the assay tubes containing PL or DAG, were added known amounts of methyl heptadecanoate as internal standards. The lipids were extracted from silica gel as described previously ${ }^{29)}$. Methyl esters of fatty acids were prepared from each extract using sodium methoxide/methanol for DAG, TAG and $\mathrm{PL}$ and using $\mathrm{HCl} /$ methanol for FFA. CE, which was extracted from silica gel, was saponified; then, the fatty acids released were extracted separately from cholesterol and converted to methyl esters using boron trifluoride/ methanol. The acyl composition of these lipids was determined as methyl esters of fatty acids by gas chromatography.

\subsection{RNA extraction and quantification of gene expression}

Total RNA was isolated from the liver tissues using
QIAzol reagent and RNeasy kit (QIAGEN, Hilden, Germany). cDNA was synthesized from 500 ng of total RNA with avian myeloblastosis virus reverse transcriptase (Takara, Shiga, Japan). Polymerase chain reaction(PCR) amplification was carried out using SYBR Premix EX Taq (2x) (Perfect Real Time; Takara). The amplification and detection were performed with Applied Biosystems 7500 real time PCR system (Life Technologies Corp., Carlsbad, CA, U.S.A.). The thermal cycling program was as follows: $10 \mathrm{~s}$ denaturation step at $95^{\circ} \mathrm{C}$, followed by 50 cycles of $5 \mathrm{~s}$ denaturation at $95^{\circ} \mathrm{C}$ and $34 \mathrm{~s}$ annealing at $60^{\circ} \mathrm{C}$. Melting curve analysis was performed to confirm the real-time PCR products. Changes in gene expression were calculated by using the comparative threshold cycle (Ct) method. Ct values were first normalized by subtracting the $\mathrm{Ct}$ value obtained from $\beta$-actin (control). The sequences of primers used in this study are listed in Table 1.

\subsection{Enzyme assays}

The activity of fatty acid synthase (FAS) in cytosol was determined by the method of Nepokroeff et $a l{ }^{37}$ ). In brief, the assay mixture contained $33 \mathrm{nmol}$ acetyl-CoA, $100 \mathrm{nmol}$ $\mathrm{NADPH}, 1 \mu \mathrm{mol}$ ethylenediaminetetraacetic acid, $1 \mu \mathrm{mol}$ 2-mercaptoethanol, $100 \mu \mathrm{g}$ of cytosolic protein and $0.1 \mathrm{M}$ potassium phosphate buffer $(\mathrm{pH}$ 7.0) in a final volume of 1 $\mathrm{mL}$. Incubation was performed at $30^{\circ} \mathrm{C}$, and the rate of NADPH-oxidation was monitored at $340 \mathrm{~nm}$. The substrate-dependent rate was determined by subtracting the NADPH oxidation rate from the rate after adding malonylCoA. Glycerol-3-phosphate acyltransferase (GPAT) activity in microsomes was determined according to Yamada and Okuyama ${ }^{38)}$ using palmitoyl-CoA and $\left[{ }^{14} \mathrm{C}\right]$ glycerol-3-phosphate. Acyl-CoA:diacylglycerol acyltransferase(DGAT) in microsomes was assayed by the method of Andersson et $a l .{ }^{39)}$ using $\left[{ }^{14} \mathrm{C}\right]$ palmitoyl-CoA and dioleoylglycerol. The activities of SCD in microsomes were determined spectrophotometrically as described previously ${ }^{29)}$ and the activity is presented as the rate constant $\left(k^{+}\right)$for stearoyl-CoA stimulated re-oxidation of NADH-reduced cytochrome $b_{5}$. Palmitoyl-CoA chain elongase (PCE) and palmitoleoyl-CoA chain elongase (POCE) in microsomes of the liver were assayed as the activities of condensation of palmitoyl-CoA or palmitoleoyl-CoA with malonyl-CoA by measuring the incorporation of $\left[2-{ }^{14} \mathrm{C}\right]$ malonyl-CoA into the exogenous acyl-CoAs essentially according to a method reported previously ${ }^{40)}$. In brief, the assay mixture contained $15 \mathrm{nmol}$ palmitoyl-CoA or palmitoleoyl-CoA, $100 \mathrm{nmol}\left[2-{ }^{14} \mathrm{C}\right]$ malonyl-CoA $(20 \mathrm{nCi}), 12 \mathrm{nmol}$ bovine serum albumin, $0.5 \mu \mathrm{mol}$ $\mathrm{KCN}, 250 \mu \mathrm{g}$ of microsomal protein and $100 \mathrm{mM}$ Tris- $\mathrm{HCl}$ ( $\mathrm{pH}$ 7.4) in a total volume of $0.5 \mathrm{~mL}$. The control value, which was obtained from incubation without acyl-CoA, was subtracted to give the net condensation rate for palmitoylCoA or palmitoleoyl-CoA. 
S. Tanaka, C. Kojiguchi, T. Yamazaki et al.

Table 1 Sequences of Primers Used for Real-Time PCR.

\begin{tabular}{|c|c|c|}
\hline & Primer $\left(5^{\prime}-3^{\prime}\right)$ & Accession No. \\
\hline \multirow[t]{2}{*}{ Fatty acid synthase (FAS) } & F: CGCCGACCAGTATAAACCCA & M76767 \\
\hline & R: GTTGTAATCGGCACCCAAGTC & \\
\hline \multirow[t]{2}{*}{ Acetyl-CoA carboxylase 1 (ACC1) } & F: AACGCCTTCACACCACCTTG & J03808 \\
\hline & R: AGTCGCAGAAGCAGCCCAT & \\
\hline \multirow[t]{2}{*}{ ATP-citrate lyase (ACLY) } & F: AAACTGTATCGCCCAGGCAGT & J05210 \\
\hline & R: GTAACGCAGCACGTGATCCAT & \\
\hline \multirow[t]{2}{*}{ Malic enzyme 1 (ME1) } & F: ACAATACAGTTTGGCATTCCG & NM_012600 \\
\hline & R: AGGATTCGCTCTCCATCAGTCA & \\
\hline \multirow[t]{2}{*}{ Glycerol-3-phosphate acyltransferase 1 (GPAT1) } & F: AGACACAGGCAGGGAATCCAC & AF021348 \\
\hline & R: AATTCCCGGAGAAGCCCAG & \\
\hline \multirow[t]{2}{*}{ Glycerol-3-phosphate acyltransferase 4 (GPAT4) } & F: TTGGAGTCCTGGAATTTGCTGA & NM_001047849 \\
\hline & R: GGCTAATCCCTGTGAATGCCA & \\
\hline \multirow[t]{2}{*}{ Acyl-CoA:diacylglycerol acyltransferase 1 (DGAT1) } & F: CCGTGGTATCCTGAATTGGT & NM_053437 \\
\hline & R: GGCGCTTCTCAATCTGAAAT & \\
\hline \multirow[t]{2}{*}{ Acyl-CoA:diacylglycerol acyltransferase 2 (DGAT2) } & F: ATCTTCTCTGTCACCTGGCT & NM_001012345 \\
\hline & R: ACCTTTCTTGGGCGTGTTCC & \\
\hline \multirow[t]{2}{*}{ Stearoyl-CoA desaturase 1 (SCD1) } & F: TCACCTTGAGAGAAGAATTAGCA & J02585 \\
\hline & R: TTCCCATTCCCTTCACTCTGA & \\
\hline \multirow[t]{2}{*}{ Stearoyl-CoA desaturase 2 (SCD2) } & F: TGCACCCCCAGACACTTGTAA & AB032243 \\
\hline & R: GGATGCATGGAAACGCCATA & \\
\hline \multirow[t]{2}{*}{ Fatty acid desaturase 1 (Fads1) } & F: TACAGGCAACCTGCAACGTTC & NM_053445 \\
\hline & R: GGTGCCACCTTGTGGTAGTTGT & \\
\hline \multirow[t]{2}{*}{ Fatty acid desaturase 2 (Fads2) } & F: GCCACTTAAAGGGTGCCTCC & $\mathrm{BC} 081776$ \\
\hline & R: TGCAGGCTCTTTATGTCGGG & \\
\hline \multirow[t]{2}{*}{ Fatty acid elongase 1 (Elovl1) } & F: CTCAGCCCTACCTTTGGTGGAA & $\mathrm{BC} 085795$ \\
\hline & R: GCAGCTGGGCATGAAGTAGTATTG & \\
\hline \multirow[t]{2}{*}{ Fatty acid elongase 2 (Elovl2) } & F: TATTCTTGCTTGCCCGTGAGA & NM_001109118 \\
\hline & R: CTGCCATTGTTGATCTGCCA & \\
\hline \multirow[t]{2}{*}{ Fatty acid elongase 5 (Elovl5) } & F: ACCACCATGCCACTATGCTCA & AB071985 \\
\hline & R: GGACGTGGATGAAGCTGTTG & \\
\hline \multirow[t]{2}{*}{ Fatty acid elongase 6 (Elovl6) } & F: AGAACACGTAGCGACTCCGAA & AB071986 \\
\hline & R: CAAACGCGTAAGCCCAGAAT & \\
\hline \multirow[t]{2}{*}{ Fatty acid translocase (FAT/CD36) } & F: CGAAGGCTTGAATCCTACCG & NM_031561 \\
\hline & R: TGTTGACCTGCAGTCGTTT & \\
\hline \multirow[t]{2}{*}{ Fatty acid transport protein 2 (FATP2) } & F: TTCAACAGTGGCGATCTCCTG & NM_031736 \\
\hline & R: ACCGGAAGGTGTCTCCAACT & \\
\hline \multirow[t]{2}{*}{ Fatty acid transport protein 4 (FATP4) } & F: CCTGGTGTACTATGGATTCCGC & NM_001100706 \\
\hline & R: GCTGAAAACTTCTTCCGGATCA & \\
\hline \multirow[t]{2}{*}{ Fatty acid transport protein 5 (FATP5) } & F: TTGCGAACGTACGGCAAGTAG & NM_024143 \\
\hline & R: AAGGCGGTCTCGGAAGTAGAAG & \\
\hline \multirow[t]{2}{*}{ Plasma membrane-associated fatty acid-binding protein (FABPpm) } & F: TCTGCCAATCCTATGCCAA & NM_013177 \\
\hline & R: CACCCTTTTGGCTTCTTC & \\
\hline \multirow[t]{2}{*}{ Fatty acid binding protein 1 (FABP1) } & F: CGGCAAGTACCAAGTGCAGAG & ВC086947 \\
\hline & R: CTGACACCCCCTTGATGTCCT & \\
\hline \multirow[t]{2}{*}{ Fatty acid binding protein 5 (FABP5) } & F: CCCTCGACAACAACAACCTCA & NM_145878 \\
\hline & R: TGCCATCAGCTGTGGTTTCA & \\
\hline Long-chain acyl-CoA synthetase 1 (ACSL1) & F: TCAGAGCAGTTCATCGGCATC & NM_012820 \\
\hline & R: GTCGGTTCCAAGCGTGTCATA & \\
\hline
\end{tabular}


Table 1 Continued.

\begin{tabular}{|c|c|c|}
\hline & Primer $\left(5^{\prime}-3^{\prime}\right)$ & Accession No. \\
\hline \multirow[t]{2}{*}{ Long-chain acyl-CoA synthetase 3 (ACSL3) } & F: GGTGGCCAAAATGTGACAATG & NM_057107 \\
\hline & R: AAACTCTCCAATATCGCCAGT & \\
\hline \multirow[t]{2}{*}{ Long-chain acyl-CoA synthetase 4 (ACSL4) } & F: ATGGCCATTGTCATGTACACCA & NM_053623 \\
\hline & R: AATCCAGGTATGCGCTCACACT & \\
\hline \multirow[t]{2}{*}{ Long-chain acyl-CoA synthetase 5 (ACSL5) } & F: CAAACATGGCTGCTTTCCTCA & NM_053607 \\
\hline & R: ACCCTGGACAAGCCTCTCAAA & \\
\hline \multirow[t]{2}{*}{ Adipose triglyceride lipase (ATGL) } & F: TCACCAACACCAGCATCCAA & NM_001108509 \\
\hline & R: TCCATCTCGGTAGCCCTGTTT & \\
\hline \multirow[t]{2}{*}{ Comparative gene identification-58 (CGI-58) } & F: TGCATAGATGGCAACTCTGGC & NM_212524 \\
\hline & R: ATACACATAATGCCCTGCCCC & \\
\hline \multirow[t]{2}{*}{ Carnitine palmitoyltransferase 1a (CPT1a) } & F: AAGGCAGCGTTCTTCGTGA & NM_031559 \\
\hline & R: GTCAAAGCATCTTCCATGC & \\
\hline \multirow[t]{2}{*}{ Medium-chain acyl-CoA dehydrogenase (MCAD) } & F: CTTTGCCTCTATTGCGAAGGC & J02791 \\
\hline & R: TCCGAAAATCTGCACAGCATC & \\
\hline \multirow[t]{2}{*}{ Long-chain acyl-CoA dehydrogenase (LCAD) } & F: TGTATTGGTGCCATAGCCATGA & L11276 \\
\hline & R: CCCAGACCTTTTGGCATTTGT & \\
\hline \multirow[t]{2}{*}{ L-type pyruvate kinase (LPK) } & F: TGTGTACCACCGCCAGTTGTT & M17685 \\
\hline & R: AGCACTTGAAGGAAGCCTCCA & \\
\hline \multirow[t]{2}{*}{ Phosphoenolpyruvate carboxykinase (PEPCK) } & F: TGCCTGGATGAAGTTTGATG & NM_198780 \\
\hline & R: GCCCGGAGCAACTCCAAAAA & \\
\hline \multirow[t]{2}{*}{ Glucokinase (GK) } & F: TGTCACCGACTGCGACATTG & M25807 \\
\hline & R: GCATGCGATTTATGACCCCA & \\
\hline \multirow[t]{2}{*}{ Glucose-6-phosphatase (G6Pc) } & F: CAGCCTCTTCAAAAACCTGG & L37333 \\
\hline & R: GAGCGACTTGCGCAGTTCTC & \\
\hline \multirow[t]{2}{*}{ Glucose transporter 2 (GLUT2) } & F: CACACCAGCACATACGACACC & NM_012879 \\
\hline & R: ACTGCAAAGCTGGACACAGA & \\
\hline \multirow[t]{2}{*}{ Sterol regulatory element binding protein-1c (SREBP-1c) } & F: GGAGCCATGGATTGCACATT & AF286469 \\
\hline & R: AGGAAGGCTTCCAGAGAGGA & \\
\hline \multirow[t]{2}{*}{ Carbohydrate responsive element-binding protein (ChREBP) } & F: AATAGAGGAGCTCAATGCT & $\mathrm{AB} 074517$ \\
\hline & R: CCCAGAACTTCCAGTTGTGC & \\
\hline \multirow[t]{2}{*}{ Peroxisome proliferator-activated receptor $\alpha(\operatorname{PPAR} \alpha)$} & F: AATGCCCTCGAACTGGATGAC & NM_013196 \\
\hline & R: CACAATCCCCTCCTGCAACTT & \\
\hline \multirow[t]{2}{*}{ Liver $\mathrm{X}$ receptor $\alpha(\mathrm{LXR} \alpha)$} & F: CCACAGCTCAGCCCAGAA & NM_031627 \\
\hline & R: GGCGTGACTCGAAGTCGGT & \\
\hline \multirow[t]{2}{*}{$\beta$-Actin } & F: TGCAGAAGGAGATTACTGCC & V01217 \\
\hline & R: CGCAGCTCAGTAACAGTCC & \\
\hline
\end{tabular}

\subsection{Statistical analyses}

Homogeneity of variance was established using one-way analysis of variance. When a difference was significant $(p<$ $0.05)$, Scheffé's multiple range test was used as a post-hoc test. The results were considered to be significant if the value of $p$ was $<0.05$.

\section{RESULTS}

3.1 Physiological parameters

Selected parameters of SHRSP were compared with those of SHR and WKY (Table 2). The body weight of SHRSP was slightly lower than those of SHR and WKY, being 80 and $76, \%$ of those of SHR and WKY, respectively. The liver weight of SHRSP was $80 \%$ of that of SHR, but there were no differences in this regard between SHRSP and WKY. The relative liver weight of SHRSP was the same as that of SHR and 128\% of that of WKY. The hepatic content of TAGs in SHRSP was 54\% of that in SHR, but there were no significant differences in this regard between WKY and SHR. No differences were observed in the hepatic contents of cholesterol between SHRSP and SHR, but the level in SHRSP was 85\% of that in WKY. No substantial dif- 
S. Tanaka, C. Kojiguchi, T. Yamazaki et al.

Table 2 Characteristics of SHRSP.

\begin{tabular}{lrrr}
\hline & WKY & \multicolumn{1}{c}{ SHR } & \multicolumn{1}{c}{ SHRSP } \\
\hline Body weight $(\mathrm{g})$ & $399.1 \pm 32.5^{\mathrm{a}}$ & $377.3 \pm 27.5^{\mathrm{a}}$ & $302.9 \pm 20.4^{\mathrm{b}}$ \\
Liver & & & \\
$\quad$ Weight $(\mathrm{g})$ & $12.8 \pm 1.2^{\mathrm{a}}$ & $15.6 \pm 1.1^{\mathrm{b}}$ & $12.5 \pm 1.5^{\mathrm{a}}$ \\
Relative weight $(\%$ of body weight) & $3.2 \pm 0.2^{\mathrm{a}}$ & $4.1 \pm 0.1^{\mathrm{b}}$ & $4.1 \pm 0.4^{\mathrm{b}}$ \\
TAG ( $\mu \mathrm{mol} / \mathrm{g}$ liver) & $6.4 \pm 1.3^{\mathrm{a}}$ & $6.4 \pm 0.5^{\mathrm{a}}$ & $3.5 \pm 1.5^{\mathrm{b}}$ \\
Cholesterol $(\mu \mathrm{mol} / \mathrm{g}$ liver) & $6.4 \pm 0.6^{\mathrm{a}}$ & $5.3 \pm 0.2^{\mathrm{b}}$ & $5.5 \pm 0.3^{\mathrm{b}}$ \\
PL $(\mu \mathrm{mol} / \mathrm{g}$ liver) & $37.0 \pm 1.7^{\mathrm{ab}}$ & $35.8 \pm 1.5^{\mathrm{a}}$ & $39.0 \pm 1.2^{\mathrm{b}}$ \\
Glycogen $(\mu \mathrm{mol} / \mathrm{g}$ liver) & $37.0 \pm 3.7^{\mathrm{a}}$ & $35.3 \pm 4.9^{\mathrm{a}}$ & $17.4 \pm 4.0^{\mathrm{b}}$ \\
Serum & & & \\
TAG $(\mathrm{mmol} / \mathrm{L})$ & $0.5 \pm 0.1^{\mathrm{a}}$ & $0.8 \pm 0.1^{\mathrm{b}}$ & $0.9 \pm 0.2^{\mathrm{b}}$ \\
Cholesterol $(\mathrm{mmol} / \mathrm{L})$ & $2.9 \pm 0.1^{\mathrm{a}}$ & $1.9 \pm 0.1^{\mathrm{b}}$ & $2.2 \pm 0.4^{\mathrm{b}}$ \\
PL $(\mathrm{mmol} / \mathrm{L})$ & $1.8 \pm 0.0^{\mathrm{a}}$ & $1.6 \pm 0.1^{\mathrm{b}}$ & $1.8 \pm 0.2^{\mathrm{ab}}$ \\
Glucose $(\mathrm{mg} / \mathrm{dL})$ & $166.9 \pm 18.9$ & $205.9 \pm 35.7$ & $174.7 \pm 14.0$ \\
\hline
\end{tabular}

Values represent means \pm SD $(n=4-5) .{ }^{a, b}$ Differences in means in the same row without a common superscript $(\mathrm{a}, \mathrm{b})$ are statistically significant $(p<0.05)$. If no superscript appears, the differences in means are not significant $(p>0.05)$.

Table 3 Fatty acid profile of hepatic lipid.

\begin{tabular}{lccc}
\hline & WKY & SHR & SHRSP \\
\cline { 2 - 4 } & \multicolumn{3}{c}{$(\mathrm{mol} \%)$} \\
\hline $16: 0$ & $25.43 \pm 1.43$ & $25.35 \pm 0.53$ & $26.71 \pm 1.14$ \\
$16: 1 \mathrm{n}-7$ & $1.35 \pm 0.34^{\mathrm{a}}$ & $1.38 \pm 0.05^{\mathrm{a}}$ & $0.85 \pm 0.18^{\mathrm{b}}$ \\
$18: 0$ & $15.79 \pm 0.93^{\mathrm{a}}$ & $15.31 \pm 0.67^{\mathrm{a}}$ & $20.05 \pm 1.57^{\mathrm{b}}$ \\
$18: 1 \mathrm{n}-9$ & $7.31 \pm 0.42^{\mathrm{a}}$ & $7.59 \pm 0.71^{\mathrm{a}}$ & $5.75 \pm 0.76^{\mathrm{b}}$ \\
$18: 1 \mathrm{n}-7$ & $4.93 \pm 0.29^{\mathrm{a}}$ & $4.50 \pm 0.21^{\mathrm{a}}$ & $2.71 \pm 0.28^{\mathrm{b}}$ \\
$18: 2 \mathrm{n}-6$ & $19.68 \pm 0.21^{\mathrm{a}}$ & $20.67 \pm 0.62^{\mathrm{a}}$ & $17.98 \pm 0.70^{\mathrm{b}}$ \\
$18: 3 \mathrm{n}-3$ & $0.31 \pm 0.02^{\mathrm{a}}$ & $0.42 \pm 0.04^{\mathrm{b}}$ & $0.21 \pm 0.02^{\mathrm{c}}$ \\
$20: 3 \mathrm{n}-6$ & $0.62 \pm 0.01$ & $0.72 \pm 0.24$ & $0.59 \pm 0.16$ \\
$20: 4 \mathrm{n}-6$ & $17.90 \pm 0.91$ & $16.91 \pm 0.30$ & $17.81 \pm 0.90$ \\
$20: 5 \mathrm{n}-3$ & $0.92 \pm 0.10^{\mathrm{a}}$ & $0.65 \pm 0.05^{\mathrm{b}}$ & $0.67 \pm 0.08^{\mathrm{b}}$ \\
$22: 5 \mathrm{n}-3$ & $1.51 \pm 0.36$ & $1.61 \pm 0.04$ & $1.21 \pm 0.20$ \\
$22: 6 \mathrm{n}-3$ & $3.80 \pm 0.64^{\mathrm{a}}$ & $4.90 \pm 0.30^{\mathrm{b}}$ & $5.36 \pm 0.36^{\mathrm{b}}$ \\
Total $(\mu \mathrm{mol} / \mathrm{g}$ liver $)$ & $90.12 \pm 3.60$ & $93.03 \pm 3.09$ & $87.62 \pm 4.76$ \\
\hline
\end{tabular}

Values represent means \pm SD $(n=4-5)$. ${ }^{a, b, c}$ Differences in means in the same without a common superscript $(\mathrm{a}, \mathrm{b}, \mathrm{c})$ are statistically significant $(p<0.05)$. If no superscript appears, the differences in means are not significant $(p>0.05)$.

ferences were observed in hepatic content of lipid phosphorus among the three groups of rats. However, the hepatic content of glycogen in SHRSP was $49 \%$ of that in SHR, but no significant difference was found in this regard between WKY and SHR. As for TAGs, cholesterol and lipid phosphorus in serum, there were no significant differences in the concentrations between SHRSP and SHR. However, the serum concentration of TAGs in SHRSP was $180 \%$ of that in WKY. In contrast, the serum level of cholesterol in SHRSP was 76\% of that in WKY, but there were no differences in serum cholesterol level between SHRSP and SHR. No substantial differences were found in the serum concentration of lipid phosphorus among WKY and SHR or SHRSP. There were also no significant differences in serum 


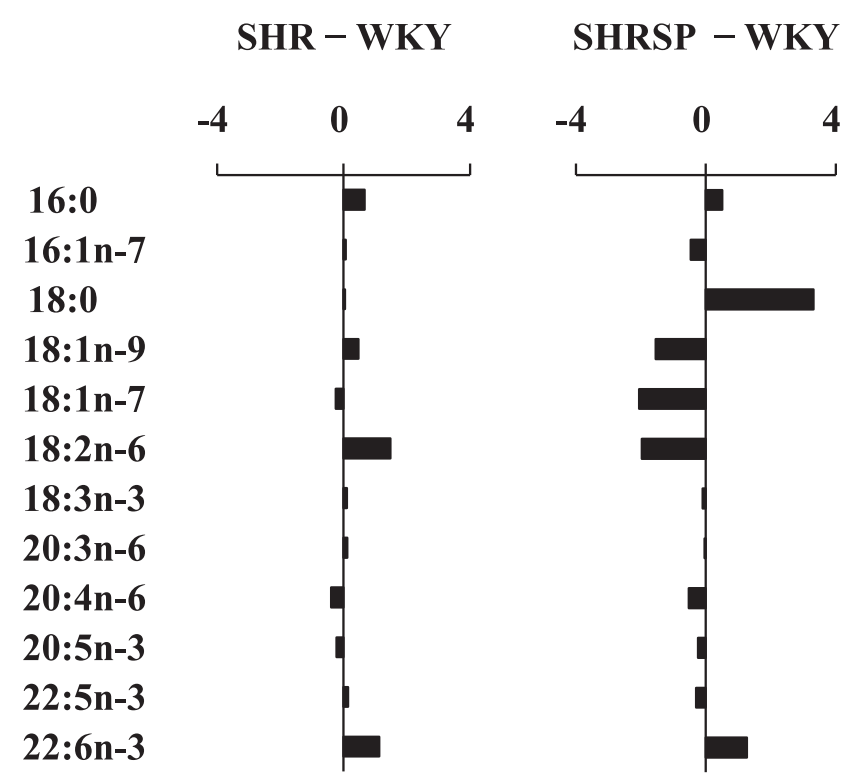

Fig. 1 Differences in content ( $\mu \mathrm{mol} / \mathrm{g}$ liver) of fatty acids in hepatic lipids between SHR and WKY and between SHRSP and WKY. With regard to each fatty acid, differences in content between the means of SHR and those of WKY and between the means of SHRSP and those of WKY were calculated from the data in Table 3.

glucose levels among the three groups of rats.

Table 3 shows the fatty acid profile (mol\%) of hepatic total lipids of SHRSP in comparison with those of SHR and WKY. In the liver of SHRSP, the proportions of palmitoleic (16:1n-7), oleic (18:1n-9), cis-vaccenic (18:1n-7), linoleic $(18: 2 \mathrm{n}-6)$ and $\alpha$-linolenic (18:3n-3) acids were $62,76,60,87$ and $50 \%$, respectively, of those of SHR; the proportion of stearic acid (18:0) was 131\% of that of SHR. However, there was no significant differences in the fatty acid profile of hepatic total lipids between WKY and SHR, except for the slightly altered proportions of $\alpha$-linolenic (18:3n-3) (increased), 5,8,11,14,17-eicosapentaenoic (20:5n-3) (decreased) and 4,7,10,13,16,19-docosahexaenoic (22:6n-3) (increased) acids. Figure 1 shows the differences in content $(\mu \mathrm{mol} / \mathrm{g}$ liver $)$ of particular fatty acids between two groups of rats. The results indicate that the dissimilarity of fatty acid profile between SHRSP and SHR was attributable to the altered contents of $16: 1 \mathrm{n}-7,18: 1 \mathrm{n}-7,18: 1 \mathrm{n}-9,18: 0$ and 18:2n-6.

\subsection{Gene expression in the liver}

The mRNA abundance of key enzymes and proteins that are involved in lipogenesis, fatty acid modification, fatty acid trafficking and lipid degradation in the liver was measured (Table 4). There were no notable differences in hepatic levels of mRNAs encoding the enzymes that are involved in de novo fatty acid synthesis (FAS, acetyl-CoA carboxylase 1(ACC1), ATP-citrate lyase (ACLY) and malic enzyme 1(ME1)) and glycerolipid synthesis (GPAT1, GPAT4, DGAT1 and DGAT2). With regard to the enzymes linked to fatty acid modification, levels of mRNAs encoding fatty acid desaturase (Fads) 2 and fatty acid elongase (Elovl) 5 in the liver of SHRSP were 342 and 67\%, respectively, of those of SHR; they were also130 and 45\%, respectively, of those of WKY. The level of Elovl5 mRNA in SHR was 67 and 149\%, respectively, of those of WKY and SHRSP. Differently from SHRSP, the expression of mRNAs for Fads2, Elovl1, Elovl2 and Elovl6 in the liver of SHR was considerably lower than that of WKY. However, there were no significant differences in the expression of genes for SCD1, SCD2 and Fads1 among the three groups of rats. As for proteins and enzymes that are involved in fatty acid trafficking, a characteristic difference was observed in the expression of mRNA encoding long-chain acyl-CoA synthetase (ACSL) 3 between SHRSP and SHR: the level of mRNA for ACSL3 in the liver of SHRSP was 66 and $69, \%$ of those of SHR and WKY, respectively. There were no significant differences in the levels of mRNAs for fatty acid translocase (FAT/CD36), fatty acid transport proteins (FATP2, FATP4 and FATP5), fatty acid binding proteins (FABP1 and FABP5), plasma membrane-associated fatty acid binding protein (FABPpm) and ACSLs (ACSL1, ACSL4 and ACSL5) between SHRSP and SHR. It is noteworthy that the levels of mRNA encoding FAT/CD36 in the liver of SHR and SHRSP were 11 and $31 \%$, respectively, of that of WKY and that the levels of mRNA encoding FABPpm in the liver of SHR and SHRSP were 55 and $65 \%$, respectively, of that of WKY. In terms of enzymes and proteins related to lipid degradation, the levels of mRNAs encoding adipose triglyceride lipase (ATGL) and carnitine palmitoyltransferase 1a (CPT1a) in the liver of SHRSP were 156 and 446\%, respectively, of those of SHR. There was no difference in the expression of the gene for medium-chain acyl-CoA dehydrogenase (MCAD) between SHRSP and SHR; their levels were approximately $60 \%$ of that of WKY. The level of mRNA for long-chain acyl-CoA dehydrogenase (LCAD) in the liver of SHRSP was significantly higher than that of SHR, but no significant difference was found in this regard between SHRSP and WKY. There were also no significant differences in the mRNA level of comparative gene identification-58 (CGI-58) among SHRSP, SHR and WKY. Concerning nuclear transcription factors, there were no differences in the levels of mRNAs for sterol regulatory element binding protein-1c (SREBP-1c), carbohydrate responsive elementbinding protein (ChREBP), peroxisome proliferator-activated receptor $\alpha(\mathrm{PPAR} \alpha)$ and liver X receptor $\alpha(\mathrm{LXR} \alpha)$ between SHRSP and SHR. The levels of expression of the gene for LXR $\alpha$ in the liver of SHR and SHRSP were 57 and $55 \%$, respectively, of that of WKY. However, there were no significant differences in the expression of the genes for L-type pyruvate kinase (LPK), phosphoenolpyruvate car- 
S. Tanaka, C. Kojiguchi, T. Yamazaki et al.

Table 4 Gene expression in the liver.

\begin{tabular}{|c|c|c|c|}
\hline Genes & WKY & SHR & SHRSP \\
\hline \multicolumn{4}{|l|}{ Lipogenesis } \\
\hline FAS & $1.0 \pm 0.19$ & $0.53 \pm 0.21$ & $0.87 \pm 0.40$ \\
\hline $\mathrm{ACC} 1$ & $1.0 \pm 0.13$ & $0.78 \pm 0.23$ & $1.14 \pm 0.42$ \\
\hline ACLY & $1.0 \pm 0.04$ & $0.89 \pm 0.24$ & $0.75 \pm 0.22$ \\
\hline ME1 & $1.0 \pm 0.39^{\mathrm{ab}}$ & $0.72 \pm 0.20^{\mathrm{a}}$ & $1.09 \pm 0.26^{\mathrm{b}}$ \\
\hline GPAT1 & $1.0 \pm 0.14$ & $0.81 \pm 0.18$ & $0.84 \pm 0.26$ \\
\hline GPAT4 & $1.0 \pm 0.21$ & $1.05 \pm 0.02$ & $0.95 \pm 0.11$ \\
\hline DGAT1 & $1.0 \pm 0.08$ & $0.91 \pm 0.14$ & $1.10 \pm 0.16$ \\
\hline DGAT2 & $1.0 \pm 0.24^{\mathrm{ab}}$ & $0.79 \pm 0.19^{\mathrm{a}}$ & $1.12 \pm 0.16^{\mathrm{b}}$ \\
\hline \multicolumn{4}{|c|}{ Fatty acid modification } \\
\hline SCD1 & $1.0 \pm 0.36$ & $0.84 \pm 0.36$ & $0.57 \pm 0.49$ \\
\hline $\mathrm{SCD} 2$ & $1.0 \pm 0.23$ & $0.75 \pm 0.19$ & $0.83 \pm 0.22$ \\
\hline Fads1 & $1.0 \pm 0.27$ & $0.90 \pm 0.11$ & $1.09 \pm 0.38$ \\
\hline Fads2 & $1.0 \pm 0.06^{\mathrm{a}}$ & $0.38 \pm 0.07^{\mathrm{b}}$ & $1.30 \pm 0.13^{\mathrm{c}}$ \\
\hline Elovl1 & $1.0 \pm 0.20^{\mathrm{a}}$ & $0.65 \pm 0.10^{\mathrm{b}}$ & $0.88 \pm 0.13^{\mathrm{a}}$ \\
\hline Elov12 & $1.0 \pm 0.29^{\mathrm{a}}$ & $0.45 \pm 0.12^{\mathrm{b}}$ & $1.19 \pm 0.38^{\mathrm{a}}$ \\
\hline Elov15 & $1.0 \pm 0.13^{\mathrm{a}}$ & $0.67 \pm 0.17^{\mathrm{b}}$ & $0.45 \pm 0.15^{\mathrm{c}}$ \\
\hline Elov16 & $1.0 \pm 0.25^{\mathrm{a}}$ & $0.24 \pm 0.15^{\mathrm{b}}$ & $0.82 \pm 0.42^{\mathrm{ab}}$ \\
\hline \multicolumn{4}{|c|}{ Fatty acid trafficking } \\
\hline FAT/CD36 & $1.0 \pm 0.59^{\mathrm{a}}$ & $0.11 \pm 0.01^{\mathrm{b}}$ & $0.31 \pm 0.11^{\mathrm{b}}$ \\
\hline FATP2 & $1.0 \pm 0.23$ & $0.79 \pm 0.12$ & $0.94 \pm 0.10$ \\
\hline FATP4 & $1.0 \pm 0.26^{\mathrm{a}}$ & $0.48 \pm 0.18^{\mathrm{b}}$ & $0.79 \pm 0.28^{\mathrm{ab}}$ \\
\hline FATP5 & $1.0 \pm 0.38^{\mathrm{a}}$ & $0.52 \pm 0.12^{\mathrm{b}}$ & $0.72 \pm 0.21^{\mathrm{ab}}$ \\
\hline FABPpm & $1.0 \pm 0.14^{\mathrm{a}}$ & $0.55 \pm 0.11^{\mathrm{b}}$ & $0.65 \pm 0.09^{b}$ \\
\hline FABP1 & $1.0 \pm 0.28^{\mathrm{a}}$ & $0.72 \pm 0.09^{\mathrm{ab}}$ & $0.55 \pm 0.21^{\mathrm{b}}$ \\
\hline FABP5 & $1.0 \pm 0.15^{\mathrm{a}}$ & $0.67 \pm 0.12^{\mathrm{ab}}$ & $0.44 \pm 0.36^{\mathrm{b}}$ \\
\hline ACSL1 & $1.0 \pm 0.20$ & $0.91 \pm 0.10$ & $0.87 \pm 0.25$ \\
\hline ACSL3 & $1.0 \pm 0.15^{\mathrm{a}}$ & $1.04 \pm 0.11^{\mathrm{a}}$ & $0.69 \pm 0.14^{\mathrm{b}}$ \\
\hline ACSL4 & $1.0 \pm 0.15$ & $0.75 \pm 0.04$ & $0.83 \pm 0.24$ \\
\hline ACSL5 & $1.0 \pm 0.05$ & $0.98 \pm 0.19$ & $0.88 \pm 0.28$ \\
\hline \multicolumn{4}{|c|}{ Lipid degradation } \\
\hline ATGL & $1.0 \pm 0.22^{\mathrm{a}}$ & $0.99 \pm 0.24^{\mathrm{a}}$ & $1.55 \pm 0.42^{\mathrm{b}}$ \\
\hline CGI-58 & $1.0 \pm 0.39$ & $0.55 \pm 0.18$ & $0.72 \pm 0.09$ \\
\hline CPT1a & $1.0 \pm 0.47^{\mathrm{a}}$ & $0.52 \pm 0.20^{\mathrm{a}}$ & $2.32 \pm 0.59^{\mathrm{b}}$ \\
\hline MCAD & $1.0 \pm 0.22^{\mathrm{a}}$ & $0.61 \pm 0.08^{\mathrm{b}}$ & $0.59 \pm 0.16^{\mathrm{b}}$ \\
\hline LCAD & $1.0 \pm 0.04^{\mathrm{a}}$ & $0.67 \pm 0.09^{\mathrm{b}}$ & $0.96 \pm 0.09^{\mathrm{a}}$ \\
\hline \multicolumn{4}{|c|}{ Glucose metabolism } \\
\hline LPK & $1.0 \pm 0.29$ & $0.90 \pm 0.19$ & $1.13 \pm 0.36$ \\
\hline PEPCK & $1.0 \pm 0.19$ & $1.06 \pm 0.28$ & $0.72 \pm 0.32$ \\
\hline GK & $1.0 \pm 0.19$ & $1.10 \pm 0.53$ & $0.85 \pm 0.46$ \\
\hline G6Pc & $1.0 \pm 0.38$ & $0.84 \pm 0.35$ & $0.68 \pm 0.37$ \\
\hline GLUT2 & $1.0 \pm 0.11$ & $0.98 \pm 0.14$ & $0.94 \pm 0.27$ \\
\hline \multicolumn{4}{|c|}{ Transcription factor } \\
\hline SREBP-1c & $1.0 \pm 0.33$ & $0.78 \pm 0.21$ & $0.75 \pm 0.18$ \\
\hline ChREBP & $1.0 \pm 0.23$ & $0.73 \pm 0.17$ & $0.80 \pm 0.28$ \\
\hline $\operatorname{PPAR} \alpha$ & $1.0 \pm 0.39$ & $0.89 \pm 0.23$ & $0.96 \pm 0.07$ \\
\hline $\mathrm{LXR} \alpha$ & $1.0 \pm 0.25^{\mathrm{a}}$ & $0.57 \pm 0.15^{\mathrm{b}}$ & $0.55 \pm 0.05^{\mathrm{b}}$ \\
\hline
\end{tabular}

Values represent means $\pm \mathrm{SD}(\mathrm{n}=4-8) .{ }^{\mathrm{a}, \mathrm{b}, \mathrm{c}}$ Differences in means in the same row without a common superscript $(\mathrm{a}, \mathrm{b}, \mathrm{c})$ are significant $(p<0.05)$. If no superscript appears, the differences in means are not significant $(p>0.05)$. 
boxykinase (PEPCK), glucokinase (GK), glucose-6-phosphatase (G6Pc) and glucose transporter 2(GLUT2) among the three groups of rats.

\subsection{Enzyme activities in the liver}

There were no significant differences in the activities of cytosolic FAS, microsomal GPAT, microsomal DGAT, microsomal SCD and microsomal PCE in the liver between SHRSP and SHR(Fig. 2A-E). The activity of DGAT in SHRSP was slightly lower (77\%) than that of WKY(Fig. 2C). The activity of POCE in hepatic microsomes of SHRSP was 60 and 38,\% of those of SHR and WKY, respectively (Fig. 2F).

\subsection{Fatty acid profiling of the liver and serum}

The fatty acid profiles of lipid classes, TAG, DAG, CE, FFA and PL, in the liver of SHRSP were compared with those of SHR and WKY(Table 5). Total contents of fatty acids of TAG and CE in the liver of SHRSP were 49 and $68 \%$, respectively, of those of SHR; however, no significant differences in the contents of fatty acids of DAG, FFA and PL were found between SHRSP and SHR. There were also no considerable differences in total fatty acid contents in all lipid classes between SHR and WKY. As for the fatty acid profiles of lipid classes, evident differences were observed in TAG, DAG, CE and PL between SHRSP and SHR. Namely, the proportions of 16:1n-7, 18:1n-7 and 18:2n-6 in TAG in the liver of SHRSP were 61,65 and $82 \%$, respectively, of those of SHR; those of 16:0 and 18:0 were 123 and $209 \%$, respectively, of those of SHR. The differences in the proportions of fatty acids in DAG between SHRSP and SHR tended to be similar to those in TAG, but they were not as pronounced. The proportions of 18:1n-9, 18:1n-7, 18:2n-6 and 20:4n-6 in CE of SHRSP were 69, 50, 40 and $29 \%$, respectively, of those of SHR; those of 16:0 and 18:0 were 141 and $138 \%$, respectively, of those of SHR. With regard to
A

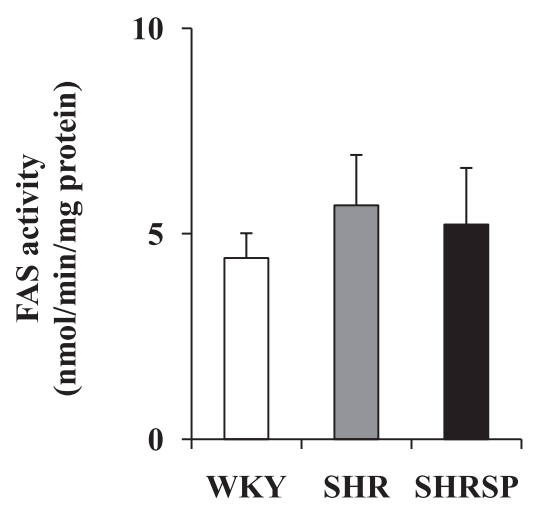

D

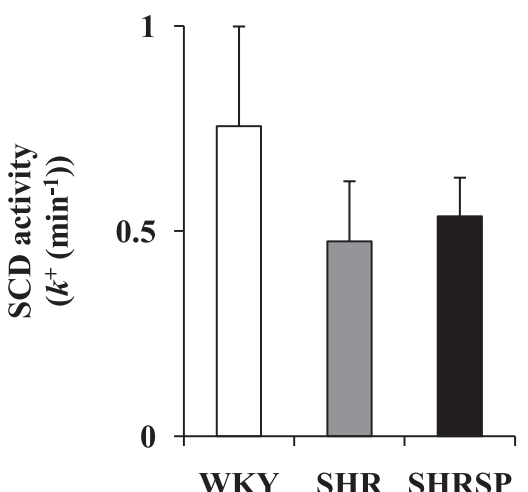

B

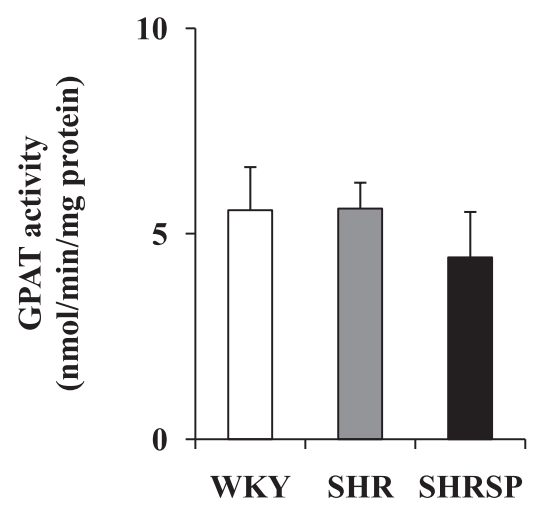

$\mathbf{E}$

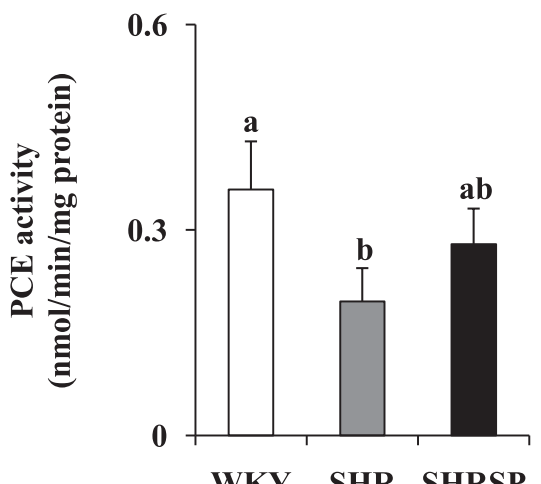

C

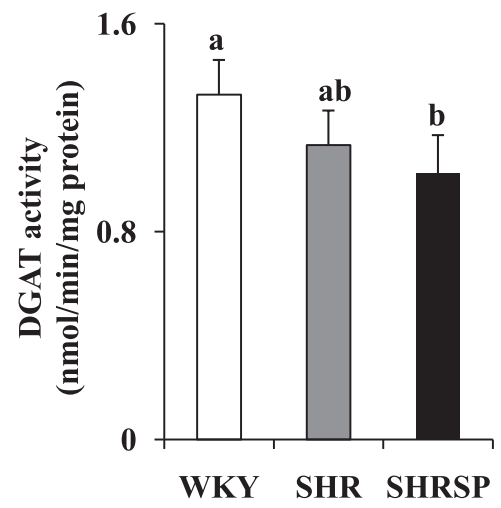

F

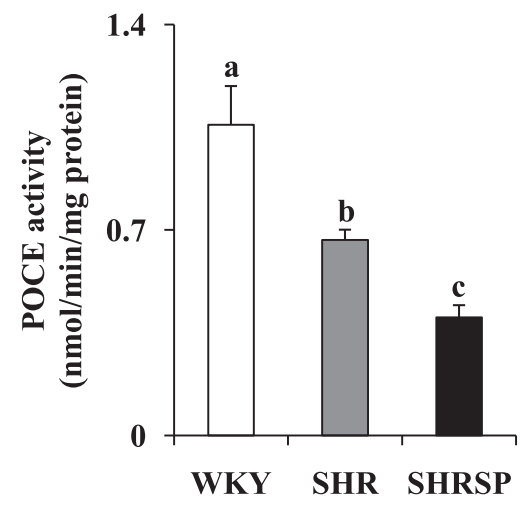

Fig. 2 Activities of enzymes involved in lipogenesis and fatty acid modification. A, FAS; B, GPAT; C, DGAT; D, $\mathrm{SCD}$; E, PCE; F, POCE. Values represent means \pm SD $(\mathrm{n}=4){ }^{\mathrm{a}, \mathrm{b}, \mathrm{c}}$ Values without a common superscript are significantly different $(p<0.05)$. If no superscript appears, the difference between the means is not significant $(p$ $>0.05$ ). 
S. Tanaka, C. Kojiguchi, T. Yamazaki et al.

Table 5 Fatty acid profile of TAG, DAG, CE, FFA and PL in the liver.

\begin{tabular}{|c|c|c|c|}
\hline & WKY & SHR & SHRSP \\
\hline & \multicolumn{3}{|c|}{$(\mathrm{mol} \%)$} \\
\hline \multicolumn{4}{|l|}{ TAG } \\
\hline $16: 0$ & $26.86 \pm 0.95^{\mathrm{a}}$ & $29.19 \pm 0.95^{\mathrm{a}}$ & $35.93 \pm 1.65^{b}$ \\
\hline $16: 1 n-7$ & $2.62 \pm 0.68^{\mathrm{a}}$ & $2.18 \pm 0.18^{\mathrm{a}}$ & $1.33 \pm 0.24^{\mathrm{b}}$ \\
\hline $18: 0$ & $3.38 \pm 0.46^{\mathrm{a}}$ & $3.17 \pm 0.26^{\mathrm{a}}$ & $6.61 \pm 2.01^{\mathrm{b}}$ \\
\hline $18: 1 n-9$ & $19.48 \pm 0.86$ & $18.66 \pm 1.06$ & $17.68 \pm 1.30$ \\
\hline $18: 1 n-7$ & $4.24 \pm 0.12^{\mathrm{a}}$ & $3.68 \pm 0.14^{\mathrm{b}}$ & $2.38 \pm 0.19^{\mathrm{c}}$ \\
\hline $18: 2 n-6$ & $30.22 \pm 0.76^{\mathrm{a}}$ & $32.30 \pm 1.11^{\mathrm{a}}$ & $26.57 \pm 2.28^{b}$ \\
\hline $18: 3 n-3$ & $1.15 \pm 0.07$ & $1.34 \pm 0.09$ & $1.10 \pm 0.19$ \\
\hline $20: 3 n-6$ & $0.41 \pm 0.07^{\mathrm{a}}$ & $0.32 \pm 0.09^{\mathrm{ab}}$ & $0.23 \pm 0.08^{\mathrm{b}}$ \\
\hline $20: 4 n-6$ & $2.90 \pm 0.41$ & $2.75 \pm 0.11$ & $2.88 \pm 0.39$ \\
\hline $20: 5 n-3$ & $1.68 \pm 0.09^{\mathrm{a}}$ & $1.31 \pm 0.21^{\mathrm{ab}}$ & $1.05 \pm 0.23^{\mathrm{b}}$ \\
\hline $22: 5 n-3$ & $2.86 \pm 0.76^{\mathrm{a}}$ & $2.24 \pm 0.08^{\mathrm{a}}$ & $1.33 \pm 0.32^{\mathrm{b}}$ \\
\hline $22: 6 n-3$ & $4.20 \pm 0.26^{\mathrm{a}}$ & $2.86 \pm 0.35^{\mathrm{b}}$ & $2.90 \pm 0.76^{\mathrm{b}}$ \\
\hline Total ( $\mu \mathrm{mol} / \mathrm{g}$ liver $)$ & $20.95 \pm 3.33^{\mathrm{a}}$ & $18.89 \pm 1.34^{\mathrm{a}}$ & $9.20 \pm 3.60^{\mathrm{b}}$ \\
\hline \multicolumn{4}{|l|}{ DAG } \\
\hline $16: 0$ & $18.51 \pm 1.22$ & $19.34 \pm 0.60$ & $18.05 \pm 1.29$ \\
\hline $16: 1 n-7$ & $2.30 \pm 0.19^{\mathrm{a}}$ & $1.83 \pm 0.07^{\mathrm{b}}$ & $1.40 \pm 0.17^{\mathrm{c}}$ \\
\hline $18: 0$ & $11.38 \pm 0.59^{\mathrm{a}}$ & $13.35 \pm 0.34^{\mathrm{a}}$ & $16.35 \pm 1.39^{\mathrm{b}}$ \\
\hline $18: 1 n-9$ & $8.83 \pm 0.30$ & $9.26 \pm 0.54$ & $7.88 \pm 1.26$ \\
\hline $18: 1 \mathrm{n}-7$ & $5.98 \pm 0.28^{\mathrm{a}}$ & $5.26 \pm 0.18^{\mathrm{b}}$ & $4.72 \pm 0.18^{\mathrm{c}}$ \\
\hline $18: 2 n-6$ & $38.21 \pm 1.40^{\mathrm{a}}$ & $36.11 \pm 1.14^{\mathrm{ab}}$ & $35.65 \pm 1.13^{\mathrm{b}}$ \\
\hline $18: 3 n-3$ & $0.53 \pm 0.03^{\mathrm{a}}$ & $0.52 \pm 0.05^{\mathrm{a}}$ & $0.32 \pm 0.06^{\mathrm{b}}$ \\
\hline $20: 3 n-6$ & $0.90 \pm 0.06$ & $0.74 \pm 0.10$ & $0.75 \pm 0.20$ \\
\hline $20: 4 n-6$ & $10.02 \pm 0.54^{\mathrm{a}}$ & $10.90 \pm 0.43^{\mathrm{a}}$ & $12.40 \pm 0.87^{b}$ \\
\hline $20: 5 n-3$ & $0.61 \pm 0.03^{\mathrm{a}}$ & $0.47 \pm 0.05^{\mathrm{ab}}$ & $0.42 \pm 0.10^{\mathrm{b}}$ \\
\hline $22: 5 n-3$ & $0.84 \pm 0.40$ & $0.88 \pm 0.12$ & $0.62 \pm 0.15$ \\
\hline $22: 6 n-3$ & $1.47 \pm 0.17$ & $1.27 \pm 0.16$ & $1.30 \pm 0.22$ \\
\hline Total ( $\mu \mathrm{mol} / \mathrm{g}$ liver $)$ & $6.20 \pm 0.45$ & $7.02 \pm 0.48$ & $6.76 \pm 0.51$ \\
\hline \multicolumn{4}{|l|}{$\mathrm{CE}$} \\
\hline 16:0 & $39.04 \pm 2.60^{\mathrm{a}}$ & $37.38 \pm 1.52^{\mathrm{a}}$ & $52.67 \pm 3.27^{\mathrm{b}}$ \\
\hline $16: 1 \mathrm{n}-7$ & $4.27 \pm 0.88^{\mathrm{ab}}$ & $3.09 \pm 0.39^{\mathrm{a}}$ & $4.76 \pm 0.61^{b}$ \\
\hline $18: 0$ & $10.20 \pm 0.26^{\mathrm{a}}$ & $12.68 \pm 1.34^{\mathrm{a}}$ & $17.51 \pm 3.49^{\mathrm{b}}$ \\
\hline $18: 1 n-9$ & $16.47 \pm 1.15^{\mathrm{a}}$ & $17.53 \pm 0.84^{\mathrm{a}}$ & $12.04 \pm 2.48^{\mathrm{b}}$ \\
\hline $18: 1 n-7$ & $2.73 \pm 0.05^{\mathrm{a}}$ & $2.32 \pm 0.21^{\mathrm{a}}$ & $1.17 \pm 0.29^{b}$ \\
\hline $18: 2 n-6$ & $15.61 \pm 0.53^{\mathrm{a}}$ & $17.21 \pm 1.69^{\mathrm{a}}$ & $6.82 \pm 2.57^{\mathrm{b}}$ \\
\hline $18: 3 n-3$ & $1.90 \pm 0.55$ & $2.73 \pm 1.52$ & $2.58 \pm 1.52$ \\
\hline $20: 3 n-6$ & $0.09 \pm 0.00^{\mathrm{a}}$ & $0.08 \pm 0.01^{\mathrm{a}}$ & $0.02 \pm 0.03^{b}$ \\
\hline $20: 4 n-6$ & $8.53 \pm 1.04^{\mathrm{a}}$ & $6.20 \pm 1.12^{\mathrm{b}}$ & $1.82 \pm 1.01^{\mathrm{c}}$ \\
\hline $20: 5 n-3$ & $0.66 \pm 0.07$ & $0.44 \pm 0.07$ & $0.49 \pm 0.32$ \\
\hline $22: 5 n-3$ & $0.00 \pm 0.00$ & $0.00 \pm 0.00$ & $0.00 \pm 0.00$ \\
\hline $22: 6 n-3$ & $0.50 \pm 0.07^{\mathrm{a}}$ & $0.34 \pm 0.06^{\mathrm{ab}}$ & $0.13 \pm 0.18^{\mathrm{b}}$ \\
\hline Total ( $\mu \mathrm{mol} / \mathrm{g}$ liver $)$ & $0.93 \pm 0.19^{\mathrm{a}}$ & $0.84 \pm 0.07^{\mathrm{a}}$ & $0.57 \pm 0.08^{\mathrm{b}}$ \\
\hline \multicolumn{4}{|l|}{ FFA } \\
\hline 16:0 & $59.77 \pm 8.22$ & $64.21 \pm 3.87$ & $64.58 \pm 2.95$ \\
\hline $16: 1 n-7$ & $1.09 \pm 0.17$ & $1.17 \pm 0.24$ & $0.98 \pm 0.25$ \\
\hline $18: 0$ & $18.38 \pm 1.86^{\mathrm{a}}$ & $13.83 \pm 0.82^{\mathrm{b}}$ & $15.82 \pm 0.98^{b}$ \\
\hline $18: 1 n-9$ & $5.51 \pm 0.34$ & $5.01 \pm 0.44$ & $5.08 \pm 0.79$ \\
\hline $18: 1 n-7$ & $2.37 \pm 0.87^{\mathrm{ab}}$ & $2.76 \pm 0.27^{\mathrm{a}}$ & $1.70 \pm 0.27^{\mathrm{b}}$ \\
\hline $18: 2 n-6$ & $5.64 \pm 2.17$ & $5.69 \pm 0.37$ & $4.98 \pm 0.67$ \\
\hline $18: 3 n-3$ & $1.56 \pm 0.12^{\mathrm{a}}$ & $1.59 \pm 0.10^{\mathrm{a}}$ & $2.31 \pm 0.46^{\mathrm{b}}$ \\
\hline $20: 3 n-6$ & $0.09 \pm 0.06$ & $0.44 \pm 0.61$ & $0.09 \pm 0.02$ \\
\hline $20: 4 n-6$ & $3.75 \pm 3.10$ & $3.20 \pm 2.18$ & $2.62 \pm 0.92$ \\
\hline $20: 5 n-3$ & $0.34 \pm 0.08$ & $0.24 \pm 0.04$ & $0.29 \pm 0.06$ \\
\hline $22: 5 n-3$ & $0.56 \pm 0.15$ & $0.48 \pm 0.04$ & $0.51 \pm 0.20$ \\
\hline $22: 6 n-3$ & $0.96 \pm 0.66$ & $1.40 \pm 0.99$ & $1.03 \pm 0.25$ \\
\hline Total ( $\mu \mathrm{mol} / \mathrm{g}$ liver $)$ & $0.69 \pm 0.25$ & $0.73 \pm 0.04$ & $0.90 \pm 0.14$ \\
\hline
\end{tabular}


Table 5 Continued.

\begin{tabular}{lccc}
\hline & WKY & SHR & SHRSP \\
\cline { 2 - 4 } & \multicolumn{3}{c}{$(\mathrm{mol} \%)$} \\
\hline PL & & \\
$16: 0$ & $22.11 \pm 0.78$ & $22.87 \pm 0.32$ & $24.18 \pm 1.44$ \\
$16: 1 \mathrm{n}-7$ & $0.74 \pm 0.17^{\mathrm{a}}$ & $0.68 \pm 0.03^{\mathrm{ab}}$ & $0.52 \pm 0.10^{\mathrm{b}}$ \\
$18: 0$ & $19.95 \pm 1.44^{\mathrm{a}}$ & $20.24 \pm 0.59^{\mathrm{a}}$ & $23.38 \pm 1.03^{\mathrm{b}}$ \\
$18: 1 \mathrm{n}-9$ & $3.65 \pm 0.19$ & $3.48 \pm 0.21$ & $3.47 \pm 0.44$ \\
$18: 1 \mathrm{n}-7$ & $4.99 \pm 0.19^{\mathrm{a}}$ & $4.57 \pm 0.21^{\mathrm{a}}$ & $2.59 \pm 0.30^{\mathrm{b}}$ \\
$18: 2 \mathrm{n}-6$ & $15.95 \pm 0.22$ & $15.91 \pm 0.91$ & $15.70 \pm 0.86$ \\
$18: 3 \mathrm{n}-3$ & $0.12 \pm 0.02$ & $0.13 \pm 0.01$ & $0.11 \pm 0.02$ \\
$20: 3 \mathrm{n}-6$ & $0.67 \pm 0.06$ & $0.58 \pm 0.09$ & $0.55 \pm 0.12$ \\
$20: 4 \mathrm{n}-6$ & $24.97 \pm 0.25^{\mathrm{a}}$ & $23.27 \pm 0.43^{\mathrm{ab}}$ & $21.30 \pm 1.50^{\mathrm{b}}$ \\
$20: 5 \mathrm{n}-3$ & $0.75 \pm 0.19^{\mathrm{a}}$ & $0.40 \pm 0.02^{\mathrm{b}}$ & $0.55 \pm 0.12^{\mathrm{ab}}$ \\
$22: 5 \mathrm{n}-3$ & $1.29 \pm 0.34$ & $1.40 \pm 0.05$ & $1.12 \pm 0.23$ \\
$22: 6 \mathrm{n}-3$ & $4.79 \pm 0.50^{\mathrm{a}}$ & $6.44 \pm 0.54^{\mathrm{b}}$ & $6.47 \pm 0.49^{\mathrm{b}}$ \\
Total $(\mu \mathrm{mol} / \mathrm{g}$ liver $)$ & $59.48 \pm 2.22^{\mathrm{a}}$ & $60.23 \pm 2.20^{\mathrm{ab}}$ & $64.19 \pm 1.95^{\mathrm{b}}$ \\
\hline
\end{tabular}

Values represent means $\pm \mathrm{SD}(\mathrm{n}=4-5)$. ${ }^{\mathrm{a}, \mathrm{b}, \mathrm{c}}$ Differences in means in the same row without a common superscript $(\mathrm{a}, \mathrm{b}, \mathrm{c})$ are statistically significant $(p<0.05)$. If no superscript appears, the differences in means are not significant $(p>0.05)$.

PL, the proportions of 18:1n-7 and 18:0 were 57 and $116 \%$, respectively, those of SHR. No substantial change was observed in the fatty acid profile of FFA in SHRSP. The alterations that were brought about in the proportions of fatty acids of these lipid classes in the liver of SHR were not as evident as those of SHRSP. Table 6 shows the fatty acid profiles of TAG and PL in serum. The proportions of 16:0, 16:1n-7, 18:1n-7 and 18:2n-6 in serum TAG of SHRSP were $115,65,74$ and $86 \%$, respectively, of those of SHR. As for serum PL, the proportions of 18:0 and 18:1n-7 in SHRSP were 113 and 59\%, respectively, of those in SHR. The proportions of 18:1n-9 in serum PL of SHR and SHRSP were slightly but significantly higher than that of WKY.

\section{DISCUSSION}

The present study clearly showed that the profile of lipid classes in the liver and serum of SHRSP was quite similar to that of SHR, except for one large difference in the hepatic content of TAGs. The content of TAGs in the liver of SHRSP was approximately half of that of SHR, suggesting that TAG metabolism is altered in the liver of SHRSP. To gain insight into the molecular basis of the alterations in TAG metabolism in the liver of SHRSP, we compared the expression of the genes encoding enzymes and proteins that are involved in lipogenesis, fatty acid trafficking and lipid degradation in the liver of SHRSP with those of SHR. Among the genes examined, the expression of the genes for ATGL and CPT1a was significantly up-regulated and that of the ACSL3 gene was down-regulated in SHRSP. On the other hand, there were no differences in the expression of genes other than the three mentioned above in the liver between SHRSP and SHR, namely the genes that encode enzymes and proteins that participate in de novo fatty acid synthesis (FAS, ACC1, ACLY and ME1) and TAG synthesis (GPAT1, GPAT4, DGAT1 and DGAT2). These results were consistent with the current data showing that no differences were found in the activities of FAS, GPAT and DGAT between SHRSP and SHR. ATGL is a key enzyme that is responsible for hydrolyzing the first fatty acid from TAGs and is considered to be a major hepatic lipase that regulates TAG turnover and fatty acid partitioning ${ }^{41}$. CPT1a is responsible for transporting long-chain fatty acids through the outer mitochondrial membrane for the purpose of $\beta$-oxidation in the mitochondrial matrix. This enzyme is considered to catalyze the rate-limiting step in $\beta$-oxidation and to play a pivotal role in controlling TAG content in the liver ${ }^{42)}$. ACSL3 has been shown to be involved in the formation of lipid droplets in conjunction with the increased production of acyl-CoAs ${ }^{43}$; moreover, ACSL3 regulates lipogenic transcription factors to control glycerolipid synthesis ${ }^{44)}$. Taking these findings together, it is logical to suggest that increases in the hydrolysis of TAG and subsequent $\beta$-oxidation of fatty acids, and a decrease in the synthesis of acyl-CoA supplied to TAG synthesis cause the reduced hepatic content of TAGs in SHRSP. In contrast to hepatic TAG, the level of TAGs in the serum of SHRSP was similar to that of SHR and was considerably higher than that of WKY. However, the detailed mechanisms by which hypertriglyceridemia is produced in SHRSP and SHR are not known. The present study also showed that cholesterol levels in the liver and serum in SHRSP as well as SHR were lower than those in WKY. These results are virtually consistent with the conclusion derived from previous studies, which demonstrated the delayed decay of cholesterol in the serum of SHRSP ${ }^{45}$ and the reduced activity of cholesterol synthesis in the liver of SHRSP ${ }^{46)}$. As a result, serum 
S. Tanaka, C. Kojiguchi, T. Yamazaki et al.

Table 6 Fatty acid profile of TAG and PL in serum.

\begin{tabular}{|c|c|c|c|}
\hline & WKY & SHR & SHRSP \\
\hline & & $(\mathrm{mol} \%)$ & \\
\hline \multicolumn{4}{|l|}{ TAG } \\
\hline $16: 0$ & $27.24 \pm 0.65^{\mathrm{a}}$ & $28.60 \pm 1.22^{\mathrm{a}}$ & $33.01 \pm 0.86^{\mathrm{b}}$ \\
\hline $16: \ln -7$ & $2.12 \pm 0.49^{\mathrm{ab}}$ & $2.53 \pm 0.26^{\mathrm{a}}$ & $1.65 \pm 0.30^{\mathrm{b}}$ \\
\hline $18: 0$ & $3.67 \pm 0.48$ & $2.56 \pm 0.39$ & $4.37 \pm 1.64$ \\
\hline $18: 1 n-9$ & $18.28 \pm 1.06$ & $20.40 \pm 0.88$ & $19.89 \pm 1.95$ \\
\hline $18: \ln -7$ & $3.53 \pm 0.20^{\mathrm{a}}$ & $3.53 \pm 0.27^{\mathrm{a}}$ & $2.61 \pm 0.18^{\mathrm{b}}$ \\
\hline $18: 2 n-6$ & $30.15 \pm 2.21^{\mathrm{ab}}$ & $33.10 \pm 1.38^{\mathrm{a}}$ & $28.48 \pm 0.85^{\mathrm{b}}$ \\
\hline $18: 3 n-3$ & $3.00 \pm 0.74^{\mathrm{a}}$ & $2.14 \pm 0.18^{\mathrm{ab}}$ & $1.61 \pm 0.12^{b}$ \\
\hline $20: 3 n-6$ & $0.27 \pm 0.06$ & $0.20 \pm 0.05$ & $0.19 \pm 0.05$ \\
\hline $20: 4 n-6$ & $3.83 \pm 1.22$ & $2.22 \pm 0.19$ & $3.06 \pm 0.96$ \\
\hline $20: 5 n-3$ & $2.39 \pm 0.31^{\mathrm{a}}$ & $1.27 \pm 0.19^{\mathrm{b}}$ & $1.33 \pm 0.50^{\mathrm{b}}$ \\
\hline $22: 5 n-3$ & $1.80 \pm 0.27^{\mathrm{a}}$ & $1.39 \pm 0.09^{\mathrm{ab}}$ & $1.04 \pm 0.28^{\mathrm{b}}$ \\
\hline $22: 6 n-3$ & $3.71 \pm 0.77^{\mathrm{a}}$ & $2.06 \pm 0.24^{\mathrm{b}}$ & $2.76 \pm 0.51^{\mathrm{ab}}$ \\
\hline Total $(\mu \mathrm{mol} / \mathrm{mL})$ & $0.95 \pm 0.23^{\mathrm{a}}$ & $1.58 \pm 0.24^{\mathrm{ab}}$ & $1.74 \pm 0.43^{\mathrm{b}}$ \\
\hline \multicolumn{4}{|l|}{ PL } \\
\hline $16: 0$ & $28.10 \pm 0.77$ & $26.68 \pm 1.89$ & $29.03 \pm 2.01$ \\
\hline $16: 1 n-7$ & $0.74 \pm 0.23$ & $0.78 \pm 0.13$ & $0.65 \pm 0.09$ \\
\hline $18: 0$ & $18.29 \pm 1.25^{\mathrm{a}}$ & $19.44 \pm 1.07^{\mathrm{a}}$ & $21.91 \pm 1.33^{b}$ \\
\hline $18: \ln -9$ & $4.28 \pm 0.21^{\mathrm{a}}$ & $5.14 \pm 0.18^{\mathrm{b}}$ & $5.49 \pm 0.28^{b}$ \\
\hline $18: \ln -7$ & $4.01 \pm 0.30^{\mathrm{a}}$ & $4.36 \pm 0.46^{\mathrm{a}}$ & $2.59 \pm 0.44^{\mathrm{b}}$ \\
\hline $18: 2 n-6$ & $21.01 \pm 1.83$ & $21.54 \pm 0.97$ & $18.97 \pm 1.57$ \\
\hline $18: 3 n-3$ & $0.59 \pm 0.38$ & $0.54 \pm 0.13$ & $0.39 \pm 0.07$ \\
\hline $20: 3 n-6$ & $0.35 \pm 0.02$ & $0.32 \pm 0.04$ & $0.37 \pm 0.10$ \\
\hline $20: 4 n-6$ & $19.05 \pm 1.07$ & $17.57 \pm 0.77$ & $16.63 \pm 1.94$ \\
\hline $20: 5 n-3$ & $0.69 \pm 0.19^{\mathrm{a}}$ & $0.43 \pm 0.08^{\mathrm{ab}}$ & $0.41 \pm 0.11^{\mathrm{b}}$ \\
\hline $22: 5 n-3$ & $0.55 \pm 0.09$ & $0.58 \pm 0.15$ & $0.44 \pm 0.08$ \\
\hline $22: 6 n-3$ & $2.35 \pm 0.36^{\mathrm{a}}$ & $2.63 \pm 0.18^{\mathrm{ab}}$ & $3.11 \pm 0.47^{\mathrm{b}}$ \\
\hline Total $(\mu \mathrm{mol} / \mathrm{mL})$ & $2.54 \pm 0.06^{\mathrm{a}}$ & $2.14 \pm 0.56^{\mathrm{b}}$ & $2.41 \pm 0.21^{\mathrm{a}}$ \\
\hline
\end{tabular}

Values represent means $\pm \mathrm{SD}(\mathrm{n}=4-5)$. ${ }^{\mathrm{a}, \mathrm{b}}$ Differences in means in the same row without a common superscript $(\mathrm{a}, \mathrm{b})$ are statistically significant $(p<0.05)$. If no superscript appears, the differences in means are not significant $(p>0.05)$.

levels of cholesterol of SHRSP and SHR were significantly lower than those of WKY. Although hepatic content of glycogen in SHRSP was considerably lower than that of SHR, there was no significant difference in the expression of genes for LPK, PEPCK, GK, G6Pc and GLUT2. Moreover, no difference was found in the serum level of glucose between SHRSP and SHR. Therefore, it is most likely that the supply of substrates for synthesis of de novo fatty acids and TAGs, acetyl-CoA and glycerol-3-phosphate, is not affected.

Another major finding of the present study is that the fatty acid profile in total hepatic lipids of SHRSP was dissimilar to that of SHR, despite the fact that there were no large differences in fatty acid profile in hepatic total lipids between SHR and WKY, except for a higher proportion of 22:6n-3 in SHR. The characteristic changes brought about in the fatty acid profile in hepatic total lipids of SHRSP were decreases in the proportions of monounsaturated fatty acids, in particular 18:1n-7, and an increase in that of 18:0. The reduced proportion of 18:1n-7 and the elevated proportion of 18:0 were common among TAG, DAG, CE and PL in the liver of SHRSP. In general, the changes in 
fatty acid profile in the liver are sequentially relayed to the fatty acid composition of serum lipids ${ }^{47}$. In accordance with the obtained findings, the changes that were brought about in the fatty acid composition of TAG and PL in the liver of SHRSP were relayed to the fatty acid profiles of TAG and PL in the serum. In particular, the decrease in proportion of 18:1n-7 was a common feature of TAG and PL in the serum of SHRSP. 18:1n-7 can be derived from the diet or biosynthetic pathway. In the liver, 18:1n-7 is synthesized from 16:0 via 16:1n-7; namely, 16:0 is desaturated by SCD1 to $16: 1 \mathrm{n}-7$, which is subsequently elongated by mainly Elovl5 to form 18:1n- $7^{48}$. It was suggested from the present results that the decreases in content and proportion of 18:1n-7 in the liver of SHRSP are responsible for metabolic alterations brought about in the liver, the changes that are due to down-regulation of the activity of POCE and the expression of the Elovl5 gene in the liver of SHRSP, but not SHR, without alterations in the activity of SCD and the expression of the SCD1 gene. The present results showed that the contents of 16:1n-7 and 18:1n-9 in the liver of SHRSP were less than those of WKY and SHR, the extents that were not so marked as the case of 18:1n-7, despite the fact that there was no significant difference in SCD activity among the three groups of animals. Moreover, the current data revealed that hepatic content of 18:0 in SHRSP was significantly greater than those of controls, despite the facts that hepatic PCE activity in SHRSP was substantially the same as those in WKY and SHR. These discrepancies between fatty acid composition and activities of SCD and PCE can be elucidated by taking the differences in distribution of individual fatty acids among lipid classes into consideration. Namely, in the liver of WKY and SHR, 18:0 that was localized in TAG was less than $5 \%$ of total 18:0; on the other hand, $16: 1 \mathrm{n}-7$ and $18: 1 \mathrm{n}-9$, but not 18:1n-7, resided in TAG in higher proportion (42-58\%) than did 18:0. It is considered that fatty acids, which are released from TAG by the action of ATGL, subsequently by other lipase (s), are prone to undergo mitochondrial $\beta$-oxidation ${ }^{49)}$. Moreover, it has been demonstrated that 18:0 is poorly oxidized by mitochondrial $\beta$-oxidation when compared to monounsaturated fatty acids ${ }^{50-52)}$. Therefore, it is likely that the content of 18:0 in hepatic lipid relatively increased and, conversely, those of 161:n-7 and 18:1n-9 relatively decreased in the liver of SHRSP compared to WKY and SHR, because the current data revealed up-regulation of ATGL and CPT1a in the liver of SHRSP.

Recently, 16:1n-7 has been identified as an adipose tissue-derived lipid hormone capable of enhancing muscle insulin sensitivity in mice ${ }^{24)}$. On the other hand, the physiologic role of 18:1n-7 has yet to be demonstrated. Recently, however, Block et al. reported that plasma PL proportions of 18:1n-7 and Framingham Risk Score are associated with chronic kidney disease, a finding suggestive of the role of 18:1n-7 in the development of chronic kidney disease ${ }^{53)}$. A more recent study has suggested a novel link between Elovl5-mediated synthesis of 18:1n-7 and gluconeogenesis in diet-induced obese mice ${ }^{20)}$. Interestingly, in a previous study, Yamori et al. demonstrated that dietary 16:1n-7 significantly improved the survival rate of SHRSP, with concomitant reduction in the incidence of stroke in spite of the excess $\mathrm{NaCl}$ intake, and that dietary 16:0, 18:1n-9, 18:2n-6 and 18:3n-3 had no effects ${ }^{12)}$. However, the authors did not show the proportion of $18: 1 n-7$, which could be synthesized from 16:1n-7 by POCE, in organs and plasma. Therefore, it is still unclear whether the preventive effects that were observed with $16: 1 \mathrm{n}-7$ are due to $16: 1 \mathrm{n}-7$ or 18:1n-7. These findings may enable one to speculate that the reduced content and proportion of $18: 1 \mathrm{n}-7$ in the liver have pathophysiological importance in the pathogenesis of disorders of the metabolism of fatty acids and TAGs in SHRSP.

In conclusion, the present study clearly showed that profiles of lipid classes and fatty acids in the liver and serum of SHRSP were significantly different from those of SHR. The characteristic alterations brought about in the liver and serum of SHRSP are(1) decreased content of TAGs in the liver, (2)altered gene expression that leads to reduced TAGs and fatty acids in the liver, (3) decreased contents and proportions of monounsaturated fatty acids, in particular 18:1n-7, in the liver and serum, and (4) the down-regulation of POCE in the liver. From the above observations, we concluded that there are significant differences in the profiles of lipid classes and fatty acids between SHRSP and SHR, and that the alterations specific for SHRSP are likely responsible for increases in TAG hydrolysis and $\beta$-oxidation, and decreases in TAG synthesis and 18:1n-7 synthesis. Considering the recently reported feature of $18: 1 \mathrm{n}-7$ as a possible signaling molecule, the results obtained in the present study may provide basic information that is valuable for studies on the etiology of disorders in lipid metabolism in SHRSP.

\section{ACKNOWLEDGEMENTS}

This work was supported by a Grant-in-Aid for Scientific Research from the Ministry of Education, Culture, Sports, Science and Technology of Japan.

\section{References}

1) Okamoto, K.; Aoki, K. Development of a strain of spontaneously hypertensive rats. Jpn. Circ. J. 27, 282-293 (1963).

2) Okamoto, K.; Yamori, Y.; Nagaoka, A. Establishment of the stroke-prone spontaneously hypertensive rat (SHR). Circ. Res. Suppl. 34/35, 143-153(1974). 
3) Yamori, Y.; Horie, R.; Handa, H.; Sato, M.; Fukase, M. Pathogenetic similarity of strokes in stroke-prone spontaneously hypertensive rats and humans. Stroke 7, 46-53(1976).

4) Akiguchi, I.; Horie, R.; Ohtaka, M.; Yamori, Y.; Kawai, C. Symptomatologic analysis of stroke in stroke-prone SHR. Jpn. Heart. J. 18, 547-548(1977).

5) Yamori, Y. Overview: studies on spontaneous hypertension-development from animal models toward man. Clin. Exp. Hypertens. A13, 631-644(1991).

6) Yamori, Y.; Nara, Y.; Mizushima, S.; Murakami, S.; Ikeda, K.; Sawamura, M.; Nabika, T.; Horie, R. Gene-environment interaction in hypertension, stroke and atherosclerosis in experimental models and supportive findings from a world-wide cross-sectional epidemiological survey: a WHO-cardiac study. Clin. Exp. Pharmacol. Physiol. Suppl. 20, 43-52(1992).

7) Nagaoka, A.; Iwatsuka, H.; Suzuoki, Z.; Okamoto, K. Genetic predisposition to stroke in spontaneously hypertensive rats. Am. J. Physiol. 230, 1354-1359 (1976).

8) Minami, M.; Togashi, H.; Koike, Y.; Saito, H.; Nakamura, N.; Yasuda, H. Changes in ambulation and drinking behavior related to stroke in stroke-prone spontaneously hypertensive rats. Stroke 16, 44-48(1985).

9) Yamori, Y.; Hamashima, Y.; Horie, R.; Handa, H.; Sato, M. Pathogenesis of acute arterial fat deposition in spontaneously hypertensive rats. Jpn. Circ. J. 39, 601-609 (1975).

10) Aitman, T. J.; Glazier, A. M.; Wallace, C. A.; Cooper, L. D.; Norsworthy, P. J.; Wahid, F. N.; Al-Majali, K. M.; Trembling, P. M.; Mann, C. J.; Shoulders, C. C.; Graf, D.; St. Lezin, E.; Kurtz, T. W.; Kren, V.; Pravenec, M.; Ibrahimi, A.; Abumrad, N. A.; Stanton, L. W.; Scott, J. Identification of Cd36 (Fat) as an insulin-resistance gene causing defective fatty acid and glucose metabolism in hypertensive rats. Nat. Genet. 21, 76-83 (1999).

11) Brosnan, M. J.; Carkner, R. D. Hepatic effects of a fructose diet in the stroke-prone spontaneously hypertensive rat. Am. J. Hypertens. 21, 708-714 (2008).

12) Yamori, Y.; Nara, Y.; Tsubouchi, T.; Sogawa, Y.; Ikeda, K.; Horie, R. Dietary prevention of stroke and its mechanisms in stroke-prone spontaneously hypertensive rats-preventive effect of dietary fibre and palmitoleic acid. J. Hypertens. Suppl. 4, S449-S452 (1986).

13) Chiang, M. T.; Otomo, M. I.; Ito, H.; Furukawa, Y.; Kimura, S. Lipoprotein, lecithin:cholesterol acyl transferase and acetyl CoA carboxylase in stroke-prone spontaneously hypertensive rats fed a diet high in eicosapentaenoic acid. Atherosclerosis 106, 21-28 (1994).

14） Katayama, Y.; Katsumata, T.; Muramatsu, H.; Usuda, K.; Obo, R.; Terashi, A. Effect of long-term administration of ethyl eicosapentate(EPA-E) on local cerebral blood flow and glucose utilization in stroke-prone spontaneously hypertensive rats (SHRSP). Brain Res. 761, 300-305 (1997).

15) Kimura, S.; Minami, M.; Saito, H.; Kobayashi, T.; Okuyama, H. Dietary docosahexaenoic acid (22: 6n-3) prevents the development of hypertension in SHRSP. Clin. Exp. Pharmacol. Physiol. Suppl. 22, S308S309 (1995).

16) Minami, M.; Kimura, S.; Endo, T.; Hamaue, N.; Hirafuji, M.; Monma, Y.; Togashi, H.; Yoshioka, M.; Saito, H.; Watanabe, S.; Kobayashi, T.; Okuyama, H. Effects of dietary docosahexaenoic acid on survival time and stroke-related behavior in stroke-prone spontaneously hypertensive rats. Gen. Pharmacol. 29, 401-407 (1997).

17) Miyazaki, M.; Takemura, N.; Watanabe, S.; Hata, N.; Misawa, Y.; Okuyama, H. Dietary docosahexaenoic acid ameliorates, but rapeseed oil and safflower oil accelerate renal injury in stroke-prone spontaneously hypertensive rats as compared with soybean oil, which is associated with expression for renal transforming growth factor-beta, fibronectin and renin. Biochim. Biophys. Acta 1483, 101-110 (2000).

18) Papazzo, A.; Conlan, X. A.; Lexis, L.; Lewandowski, P. A. Differential effects of dietary canola and soybean oil intake on oxidative stress in stroke-prone spontaneously hypertensive rats. Lipids Health Dis. 10, 98 (2011).

19) Burns, T. A.; Kadegowda, A. K. G.; Duckett, S. K.; Pratt, S. L.; Jenkins, T.C. Palmitoleic (16:1 cis-9) and cis-vaccenic (18:1 cis-11) acid alter lipogenesis in bovine adipocyte cultures. Lipids 47, 1143-1153(2012).

20) Tripathy, S.; Jump, D. B. Elovl5 regulates the mTORC2-Akt-FOXO1 pathway by controlling hepatic cis-vaccenic acid synthesis in diet-induced obese mice. J. Lipid Res. 54, 71-84(2013).

21） Miyazaki, M.; Kim, Y. C.; Gray-Keller, M. P.; Attie, A. D.; Ntambi, J. M. The biosynthesis of hepatic cholesterol esters and triglycerides is impaired in mice with a disruption of the gene for stearoyl-CoA desaturase 1. J. Biol. Chem. 275, 30132-30138(2000).

22) Dixon, J. L.; Furukawa, S.; Ginsberg, H. N. Oleate stimulates secretion of apolipoprotein B-containing lipoproteins from Hep G2 cells by inhibiting early intracellular degradation of apolipoprotein B. J. Biol. Chem. 266, 5080-5086 (1991).

23) Akazawa, Y.; Cazanave, S.; Mott, J. L.; Elmi, N.; Bronk, S. F.; Kohno, S.; Charlton, M. R.; Gores, G. J. Palmitoleate attenuates palmitate-induced Bim and PUMA up-regulation and hepatocyte lipoapoptosis. J. Hepatol. 52, 586-593 (2010).

24) Cao, H.; Gerhold, K.; Mayers, J. R.; Wiest, M. M.; Watkins, S. M.; Hotamisligil, G. S. Identification of a lipo- 
kine, a lipid hormone linking adipose tissue to systemic metabolism. Cell 134, 933-944(2008).

25) Gillingham, L. G.; Harris-Janz, S.; Jones, P. J. H. Dietary monounsaturated fatty acids are protective against metabolic syndrome and cardiovascular disease risk factors. Lipids 46, 209-228(2011).

26) Stefan, N.; Peter, A.; Cegan, A.; Staiger, H.; Machann, J.; Schick, F.; Claussen, C. D.; Fritsche, A.; Häring, H. U.; Schleicher, E. Low hepatic stearoyl-CoA desaturase 1 activity is associated with fatty liver and insulin resistance in obese humans. Diabetologia 51, 648-656 (2008).

27) Li, Z. Z.; Berk, M.; McIntyre, T. M.; Feldstein, A. E. Hepatic lipid partitioning and liver damage in nonalcoholic fatty liver disease: role of stearoyl-CoA desaturase. J. Biol. Chem. 284, 5637-5644 (2009).

28) Okamoto, H.; Kawaguchi, H.; Minami, M.; Saito, H.; Yasuda, H. Lipid alterations in renal membrane of stokeprone spontaneously hypertensive rats. Hypertension 13, 456-462 (1989).

29) Imai, K.; Koyama, M.; Kudo, N.; Shirahata, A.; Kawashima, Y. Increase in hepatic content of oleic acid induced by dehydroepiandrosterone in the rat. Biochem. Pharmacol. 58, 925-933(1999).

30) Lowry, O. H.; Rosebrough, N. J.; Farr, A. L.; Randall, R. $\mathrm{J}$. Protein measurement with the folin phenol reagent. J. Biol. Chem. 193, 265-275(1951).

31) Bligh, E. G.; Dyer, W. J. A rapid method of total lipid extraction and purification. Can. J. Biochem. Physiol. 37, 911-917(1959).

32) Zurkowski, P. A rapid method for cholesterol determination with a single reagent. Clin. Chem. 10, 451-453 (1964).

33) Rouser, G.; Siakotos, A. N.; Fleischer, S. Quantitative analysis of phospholipids by thin-layer chromatography and phosphorus analysis of spots. Lipids 1, 85-86 (1966).

34) Flowers, M. T.; Groen, A. K.; Oler, A. T.; Keller, M. P.; Choi, Y.; Schueler, K. L.; Richards, O. C.; Lan, H.; Miyazaki, M.; Kuipers, F.; Kendziorski, C. M.; Ntambi, J. M.; Attie, A. D. Cholestasis and hypercholesterolemia in SCD1-deficient mice fed a low-fat, high-carbohydrate diet. J. Lipid Res. 47, 2668-2680 (2006).

35) Keppler, D.; Decker, K. Glycogen: determination with amyloglucosidase. Methods of Enzymatic Analysis (Bergmeyer, H.U. ed.) Vol. 3, Academic Press, New York, pp. 1127-1131 (1974).

36) Yamazaki, T.; Wakabayashi, M.; Ikeda, E.; Tanaka, S.; Sakamoto, T.; Mitsumoto, A.; Kudo, N.; Kawashima, Y. Induction of 1-acylglycerophosphocholine acyltransferase genes by fibrates in the liver of rats. Biol. Pharm. Bull. 35, 1509-1515(2012).

37) Nepokroeff, C. M.; Lakshmanan, M. R.; Porter, J. W. Fatty acid synthase from rat liver. Methods in Enzy- mology (Lowenstein, J. M. ed.) Vol. 35, Academic Press, New York, pp. 37-44 (1975).

38) Yamada, K.; Okuyama, H. Selectivity of diacylglycerophosphate synthesis in subcellular fractions of rat liver. Arch. Biochem. Biophys. 190, 409-420 (1978).

39) Andersson, M.; Wettesten, M.; Borén, J.; Magnusson, A.; Sjöberg, A.; Rustaeus, S.; Olofsson, S. O. Purification of diacylglycerol:acyltransferase from rat liver to near homogeneity. J. Lipid Res. 35, 535-545 (1994).

40） Nagi, M. N.; Cook, L.; Suneja, S. K.; Osei, P.; Cinti, D. L. Spectrophotometric assay for the condensing enzyme activity of the microsomal fatty acid chain elongation system. Anal. Biochem. 179, 251-261 (1989).

41) Ong, K. T.; Mashek, M. T.; Bu, S. Y.; Greenberg, A.S.; Mashek, D. G. Adipose triglyceride lipase is a major hepatic lipase that regulates triacylglycerol turnover and fatty acid signaling and partitioning. Hepatology 53, 116-126 (2011).

42) Stefanovic-Racic, M.; Perdomo, G.; Mantell, B. S.; Sipula, I. J.; Brown, N. F.; O’Doherty, R. M. A moderate increase in carnitine palmitoyltransferase 1a activity is sufficient to substantially reduce hepatic triglyceride levels. Am. J. Physiol. Endocrinol. Metab. 294, E969-E977 (2008).

43) Fujimoto, Y.; Itabe, H.; Kinoshita, T.; Homma, K. J.; Onoduka, J.; Mori, M.; Yamaguchi, S.; Makita, M.; Higashi, Y.; Yamashita, A.; Takano, T. Involvement of ACSL in local synthesis of neutral lipids in cytoplasmic lipid droplets in human hepatocyte HuH7. J. Lipid Res. 48, 1280-1292 (2007).

44) Bu, S. Y.; Mashek, M. T.; Mashek, D. G. Suppression of long chain acyl-CoA synthetase 3 decreases hepatic de novo fatty acid synthesis through decreased transcriptional activity. J. Biol. Chem. 284, 30474-30483 (2009).

45) Iritani, N.; Nara, Y.; Yamori, Y. Cholesterol and bile acid metabolism in hypertensive arteriolipidosis-prone rats (ALR). Jpn. Circ. J. 46, 151-155(1982).

46) Sawamura, M.; Nara, Y.; Yamori, Y. Liver mevalonate 5 -pyrophosphate decarboxylase is responsible for reduced serum cholesterol in stroke-prone spontaneously hypertensive rat. J. Biol. Chem. 267, 6051-6055 (1992).

47) Kawashima, Y.; Mizuguchi, H.; Kozuka, H. Modulation by dietary oils and clofibric acid of arachidonic acid content in phosphatidylcholine in liver and kidney of rat: effects on prostaglandin formation in kidney. Biochim. Biophys. Acta 1210, 187-194(1994).

48) Green, C. D.; Ozguden-Akkoc, C. G.; Wang, Y.; Jump, D. B.; Olson, L. K. Role of fatty acid elongases in determination of de novo synthesized monounsaturated fatty acid species. J. Lipid Res. 51, 1871-1877 (2010).

49) Lankester, D. L.; Brown, A. M.; Zammit, V. A. Use of cytosolic triacylglycerol hydrolysis products and of ex- 
ogenous fatty acid for the synthesis of triacylglycerol secreted by cultured rat hepatocytes. J. Lipid Res. 39, 1889-1895 (1998).

50) Bergouignan, A.; Momken, I.; Schoeller, D. A.; Simon, C.; Blanc, S. Prog. Lipid Res., 48, 128-147 (2009).

51) Miyazawa, S.; Furuta, S.; Hashimoto, T. Reduction of $\beta$-oxidation capacity of rat liver mitochondria by feeding orotic acid. Biochim. Biophys. Acta 711, 494-502 (1982).

52) Mannaerts, G. P.; Debeer, L. J.; Thomas, J.; De Schep- per, P. J. Mitochondrial and peroxisomal fatty acid oxidation in liver homogenates and isolated heptocytes from control and clofibrate-treated rats. J. Biol. Chem. 254, 4585-4595(1979).

53) Block, R.; Kakinami, L.; Liebman, S.; Shearer, G. C.; Kramer, H.; Tsai, M. Cis-vaccenic acid and the Framingham risk score predict chronic kidney disease: the multi-ethnic study of atherosclerosis (MESA). Prostaglandins Leukot. Essent. Fatty Acids 86, 175-182 (2012). 